University of Louisville

ThinkIR: The University of Louisville's Institutional Repository

Electronic Theses and Dissertations

$12-2016$

\title{
Mechanism of interaction of peptide modified nanoparticles with Porphyromonas gingivalis.
}

Ankita Jain

University of Louisville

Follow this and additional works at: https://ir.library.louisville.edu/etd

Part of the Nanomedicine Commons, Oral Biology and Oral Pathology Commons, Other Biomedical Engineering and Bioengineering Commons, and the Pharmaceutics and Drug Design Commons

\section{Recommended Citation}

Jain, Ankita, "Mechanism of interaction of peptide modified nanoparticles with Porphyromonas gingivalis." (2016). Electronic Theses and Dissertations. Paper 2581.

https://doi.org/10.18297/etd/2581

This Master's Thesis is brought to you for free and open access by ThinkIR: The University of Louisville's Institutional Repository. It has been accepted for inclusion in Electronic Theses and Dissertations by an authorized administrator of ThinkIR: The University of Louisville's Institutional Repository. This title appears here courtesy of the author, who has retained all other copyrights. For more information, please contact thinkir@louisville.edu. 


\title{
MECHANISM OF INTERACTION OF PEPTIDE MODIFIED NANOPARTICLES WITH PORPHYROMONAS GINGIVALIS
}

\section{By}

Ankita Jain

B.D.S, Himachal Pradesh University, 2009

\section{A Thesis Submitted to the Faculty of the School of Dentistry of the University of Louisville in Full Fulfilment of the Requirements for the Degree of}

\author{
Master of Science \\ In Oral Biology
}
Department of Oral Immunology and Infectious Diseases
School of Dentistry
University of Louisville
Louisville, KY

December 2016 
Copyright by Ankita Jain in 2016

All Rights Reserved 

MECHANISM OF INTERACTION OF PEPTIDE MODIFIED NANOPARTICLES

WITH PORPHYROMONAS GINGIVALIS

By

Ankita Jain

B.D.S., Himachal Pradesh University, 2009

Thesis Approved on

November 30, 2016

By the following Thesis Committee:

Dr. Donald R. Demuth. Ph. D.

Thesis Director

Dr. Jill M. Steinbach-Rankins, Ph.D.

Committee Member

Dr. Kenneth E. Palmer, Ph.D.

Co mmittee Member

Dr. David A. Scott, Ph. D.

Committee Member 


\section{DEDICATION}

To my husband Akash Ajmera 


\section{ACKNOWLEDGEMENTS}

The completion of this project could not have been possible without the participation and assistance of a lot of people whose names may not all be enumerated. Their contributions are sincerely appreciated and gratefully acknowledged.

Foremost, I want to thank The Great Almighty, the author of knowledge and wisdom, for his countless love.

I would like to express the deepest appreciation to my committee chair, Dr. Donald R. Demuth and my co-mentors Dr. Jill Steinbach-Rankins and Dr. Kenneth E. Palmer who continually and convincingly conveyed a spirit of adventure in regard to research. I want to thank them, specifically, for improving on my written and oral scientific communication skills. Without their guidance and persistent help, this dissertation would not have been possible. I would also like to thank my committee member Dr. David A. Scott for being patient and supportive and for an understanding spirit during my presentations.

I am extremely grateful to Jinlian Tan and Kamruzzaman Rocky, for their endless help in all the stages of my research project. A very special thank you for providing me with valuable guidance during my experiments.

I would like to heartily thank my in-laws, Dipti Ajmera, Vijay Ajmera and Badal Ajmera for believing in me and supporting me to their utmost. I want to offer my thanks to all my friends, Harsha, Satya, Kanika, Aradhika, Shubham, Margi, Celine, Paridhi for always being there for me.

I would like to thank my parents, Pankaj Jain and Kiran Jain, along with my brother Aayush Jain, without whose support I would never have been able to commence pursuing my dreams. Their emotional, physical, financial and spiritual presence brought me this far. I cannot thank them enough for the deepest love they have bestowed upon me.

Last but not the least, I cannot appreciate enough for what my husband, Akash Ajmera, has done for me during this one and a half year of my research project. $\mathrm{He}$ has continuously been my inspiration, has motivated and encouraged me in all phases and has been my pillar of strength. This dissertation would not have been possible if it wasn't for him. 


\begin{abstract}
MECHANISM OF INTERACTION OF PEPTIDE MODIFIED NANOPARTICLES

WITH PORPHYROMONAS GINGIVALIS
\end{abstract}

Ankita Jain

November 30, 2016

Studies suggest that $P$. gingivalis functions as a keystone pathogen and interacts with primary colonizers in the supragingival biofilm such as S. gordonii. This interaction contributes to the initial colonization of the oral cavity by $P$. gingivalis and thus represents a potential target for therapeutic intervention. We have identified a peptide (BAR) derived from the streptococcal SspB protein that functions to inhibit $P$. gingivalis adherence to $S$. gordonii. In addition, we showed that nanoparticles (NPs) functionalized with BAR inhibit this interaction more potently than free soluble peptide, possibly by promoting interaction with $P$. gingivalis at higher valency than free peptide and increasing the avidity of the interaction. Two approaches were used to assess the valency of BAR- $P$. gingivalis interaction. First NPs were conjugated with various defined amounts of BAR. The resulting NPs were tested for inhibition of $P$. gingivalis adherence using a two-species biofilm model and the results were compared with inhibition by free peptide. Nanoparticle preparations were synthesized in the presence of 
increasing amounts of fluorescently labeled or unlabeled BAR. We found that peptide bound to nanoparticles increased in a dose dependent manner ranging from $1.20 \mu \mathrm{g} \mathrm{BAR} / \mathrm{mg}$ of NPs to $5.87 \mu \mathrm{g}$ BAR/mg of NPs. We tested them for inhibition in the biofilm assay. We observed dose-dependent efficacy based on the amount of BAR peptide on the nanoparticle surface. Valency of BAR peptide directly correlated to increased inhibition. Second, inhibition of adherence was also determined using BAR-antibody fusion proteins in dimer and tetramer form. Peptide-antibody fusions were produced using a plant based production platform and tested as above. We designed nucleic acid constructs that encoded BARantibody fusion proteins containing two or four molar equivalents of BAR. The fusion protein containing two equivalents of BAR was successfully expressed whereas the protein containing 4 BAR equivalents appeared to be toxic to cells expressing the protein. The fusion protein containing two BAR molecules showed a dose-dependent increase in the percent inhibition as the amount of the BAR peptide increased However, the Ab-BAR fusion peptide was not more potent than soluble BAR peptide. Increasing the valency of the BAR-P. gingivalis interaction may pave the way for development of more potent therapeutics that target the initial colonization of the oral cavity by P. gingivalis. 


\section{TABLE OF CONTENTS}

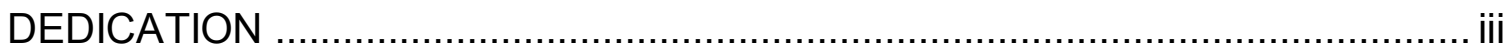

ACKNOWLEDGEMENTS .............................................................................. iv

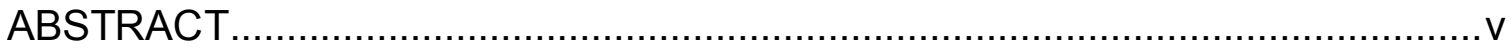

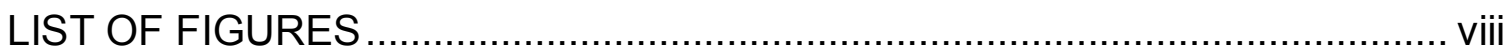

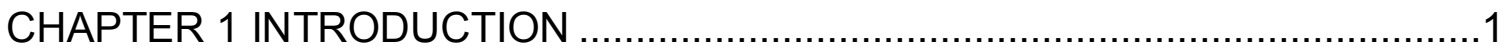

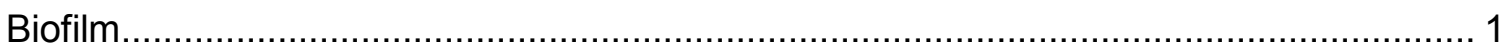

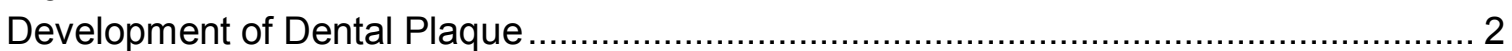

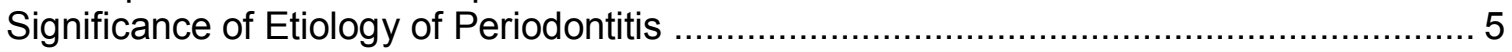

$P$. gingivalis and its interaction pattern ........................................................... 7

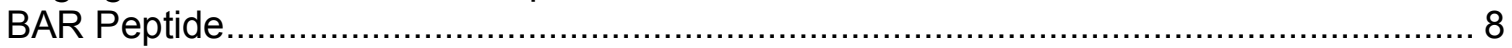

Advantages of Nanoparticles as advanced therapeutics ......................................... 9

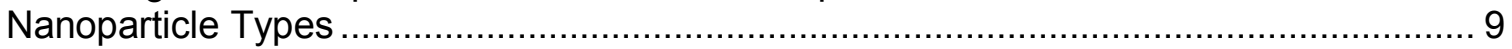

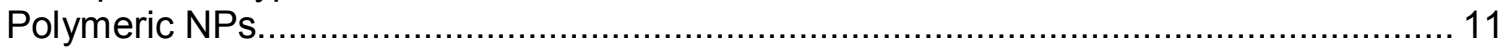

Polymeric NPs have demonstrated biocompatibility and flexible tuning of physical properties enabling the drug release and dosage profiles. There are many types of polymeric NPs including poly (lactic acid) (PLA), poly( $\varepsilon$-caprolactone) $(\mathrm{PCL})$,

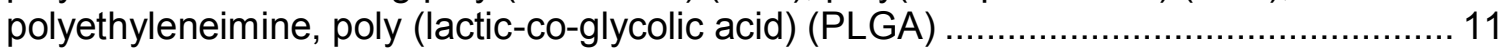

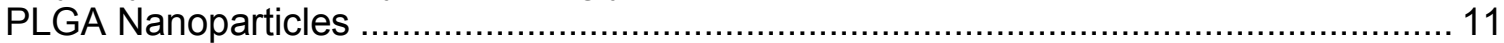

Drug delivery by binding to Immunoglobulins ....................................................... 13

Various types of Fusion Proteins (Genetic fusion to Immunoglobulins) ......................... 14

CHAPTER 2 HYPOTHESIS AND SPECIFIC AIMS ........................................16

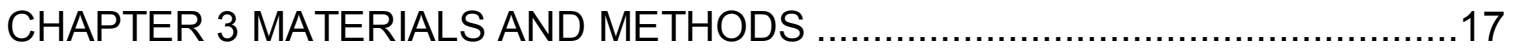

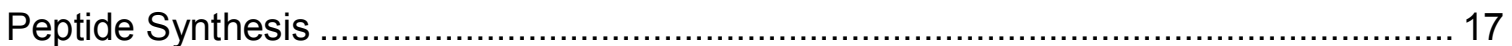

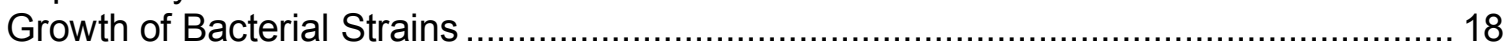

Avidin-Palmitic Acid Conjugation ....................................................................... 18

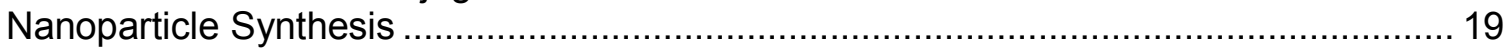

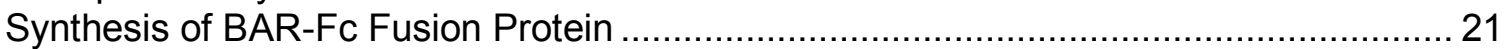

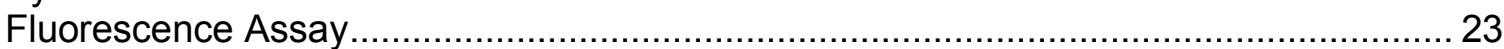

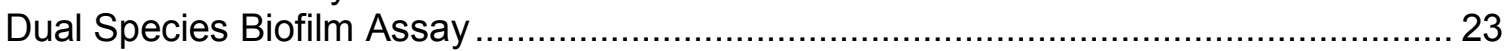

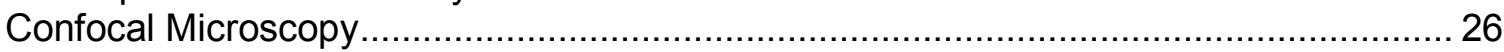

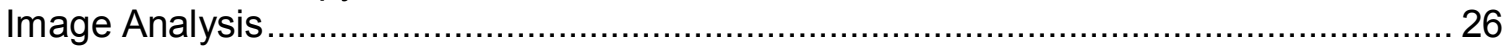

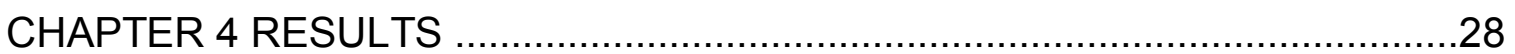

Surface Modification Efficacy of PLGA NPs with BAR Peptide .................................... 28

Biofilm Inhibition Assay with BAR-NPs................................................................. 31

Biofilm Inhibition Assay with BAR-Fc Fusion ……………….................................. 38

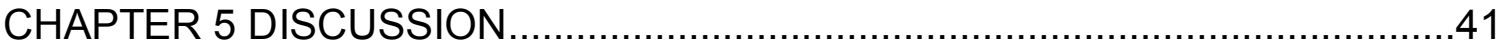

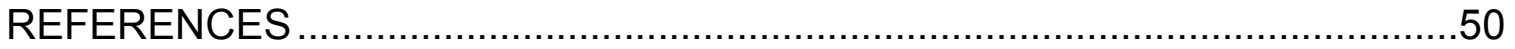

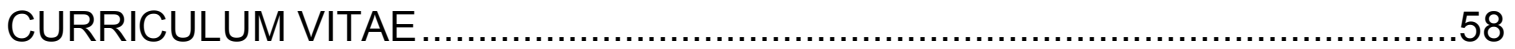




\section{LIST OF FIGURES}

Figure 1 Schematic of Stages in Biofilm Formation.............................02

Figure 2 Comparison of Multivalent and Monovalent Interaction.................13

Figure 3 Oil-in-Water Single Emulsion Technique for Nanoparticle synthesis.....20

Figure 4 Ab-BAR Fusion, Dimer, Fc........................................22

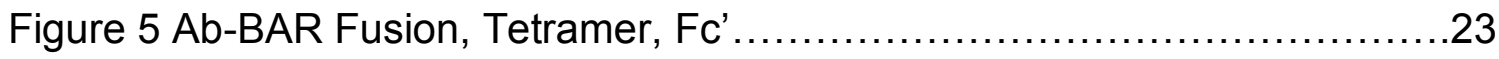

Figure 6 Standard Curve for free BAR peptide ................................29

Figure 7 Saturation Curve for fluorescently labeled BAR peptide $\ldots \ldots \ldots \ldots \ldots \ldots \ldots .29$

Figure 8 \& 9 BAR-Np Inhibition of $P$. gingivalis adherence to $S$.

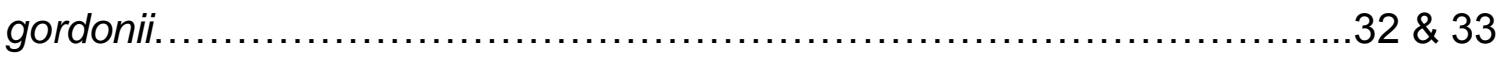

Figure 10 Inhibition curves showing BAR concentration versus percent

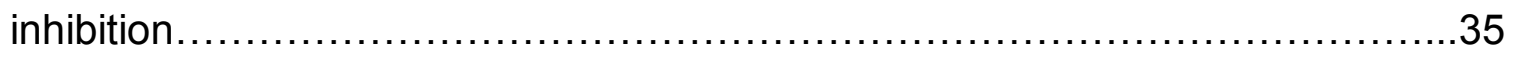

Figure $11 \mathrm{IC}_{50}$ curve showing biofilm inhibition vs Input BAR concentration (BAR-

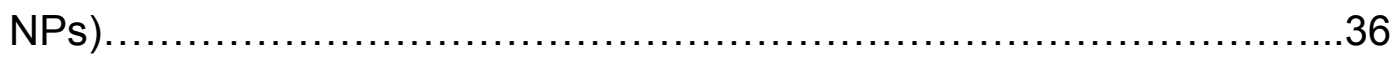

Figure 12 BAR-Fc Inhibition of $P$. gingivalis adherence to $S$. gordonii...........38 


\section{CHAPTER 1}

\section{INTRODUCTION}

Periodontitis is one of the most ubiquitous diseases and is characterized by the destruction of connective tissue and dental bone support following an inflammatory host response secondary to infection by periodontal bacteria (AlJehani, 2014). It is the most common disease of the oral cavity, affecting soft and hard structures that support the teeth, and has many clinical outcomes including loss of attachment, bone loss and eventually tooth loss (Albandar, 2011; Dhadse et al, 2010). Periodontitis is second only to dental caries as a cause of tooth loss among adults in developed countries (Gautam et al., 2011). A study entitled Prevalence of Periodontitis in Adults in the United States: 2009 and 2010 estimates that 47.2 percent of the American adults or 64.7 million Americans have mild, moderate or severe periodontitis (Eke et al., 2015). In adults, 65 years and older, the prevalence rate increases to 70.1 percent ( Eke et al., 2015). Other studies have demonstrated that mild forms of periodontitis affect $75 \%$ of adults in the United States and more severe forms affect 20 to $30 \%$ of adults (Dhadse, et al, 2010). A study conducted combined the data from the 
2009 to 2010 and 2011 to 2012 cycles of the National Health and Nutrition Examination Survey (NHANES). It concluded high prevalence of periodontitis in US adults aged $\geq 30$ years, with almost fifty-percent affected (Eke et al., 2015). In the early stage of periodontitis, termed gingivitis, gums become swollen and red due to inflammation, which is the body's natural response to the presence of harmful bacteria. The colonization of bacteria in the supragingival area initiates an inflammatory response which leads to periodontitis (Brogden \& Guthmiller, 2002; Dickinson et al., 2011). Currently, treatments like removal of dental plaque, antibiotic therapy or gingival surgery (if required) may help to cure periodontitis. No therapeutic method has been devised to actually prevent the colonization of bacteria, thereby, preventing biofilm formation.

\section{Biofilm}

A biofilm is a structured community of micro-organisms that is adhered to a surface and enclosed in a self-generated matrix (consisting of carbohydrate polymers, proteins, and DNA) (Donlan, 2002). Microbial biofilms are known to cause a number of infectious diseases in humans, a few of which include tonsillitis, dental disease, urinary tract infections and endocarditis (Bjarnsholt, 2013). Dental plaque is a complex oral multispecies biofilm that adheres to the teeth and consists of many species of both fungal and bacterial cells. According to World Health Organization, it is a specific but highly variable structural entity resulting from sequential colonization and growth of microorganisms on the surfaces of teeth and/or restorations (Rosan \& Lamont, 
2000). The biofilm consists of microorganisms of various species embedded in an extracellular matrix composed of bacterial metabolic products and substances from serum, saliva and blood. This accumulation of microorganisms subjects the teeth and gingival tissues to high concentrations of bacterial metabolites, often resulting in gingivitis and eventually periodontitis. Therefore, understanding the development of dental plaque and the corresponding etiology of periodontitis would help to develop therapeutics to prevent or cure periodontitis.

\section{Development of Dental Plaque}

The formation of biofilms occurs in a multistep progression (O'Toole et al, 2000). Obtaining a better understanding of the mechanisms of bacterial attachment and co-adhesion could lead to strategies to control or influence the pattern of biofilm formation. Distinct stages in plaque formation include the following stages depicted in Figure 1 (Chandki et al, 2011; Dickinson et al., 2011; Marsh, 2006)

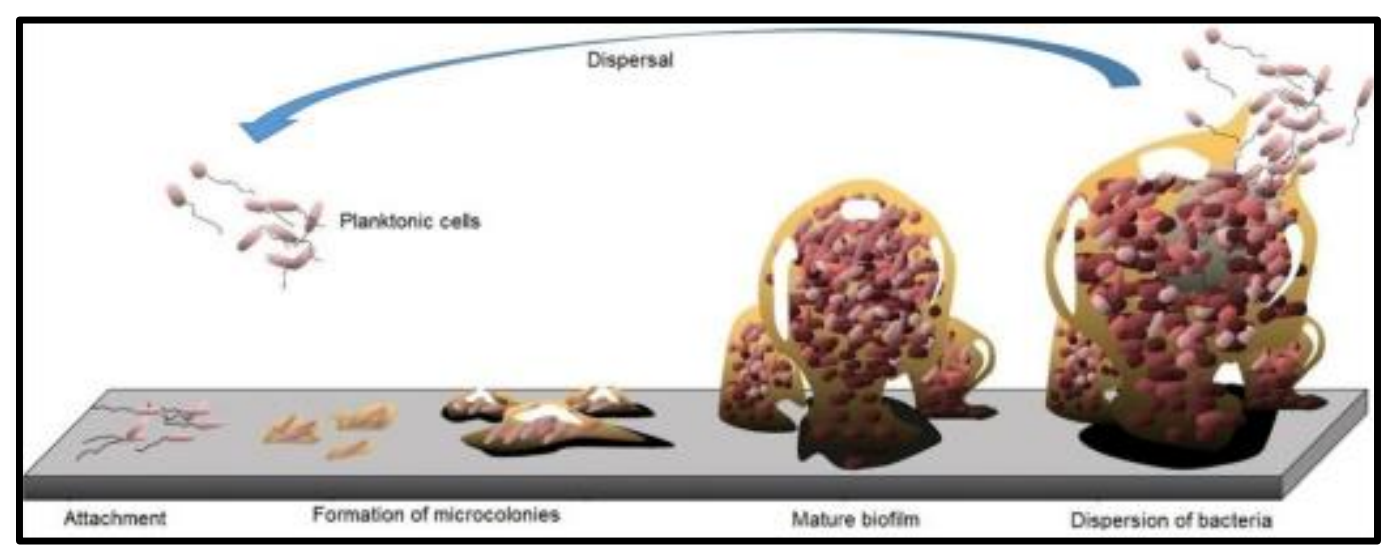

Figure 1: Stages in biofilm formation. * adapted from wikipedia.org/wiki/File:Biofilm.jpg

Plaque formation begins with the formation of the acquired pellicle (Diaz et al., 2006). The pellicle is a thin coating of salivary proteins that adheres to the tooth 
surface within minutes after tooth eruption or cleaning (Armstrong, 1968). The pellicle is composed of albumin, glycoproteins, acidic proline-rich proteins, mucins, cell debris, amylase, lysozyme and sialic acid (Lindh et al, 2014). The pellicle provides a sticky base to support further microbial colonization (Lindh et al., 2014). Acidic phosphoproteins and proline-rich proteins mediate initial interactions with primary colonizing organisms, which are comprised largely of Gram-positive cocci, including streptococcal species (Marsh, 1994; Marsh, 2006).

After pellicle formation, reversible adhesion contributes to the beginning of bacterial cell attachment (Garrett et al, 2008). Reversible adhesion involves weak long-range physicochemical interactions between the cell surface and the pellicle, which can lead to stronger adhesin-receptor mediated attachment (Garrett et al., 2008). Reversible adhesion is initiated with a single cell adhering to the surface from a 'planktonic' state, in which the bacteria are freely floating in the solution that bathes the oral cavity (Garrett et al., 2008). This change from the 'planktonic' state is usually associated with the change in the expression of genes and also the phenotype leading to the adaptation of bacterial cell lifestyle from the planktonic environment to the environment on the tooth surface. After reversible adhesion, the cells start to proliferate and form microcolonies. This process may increase the diversity of the biofilm through co-adhesion between different species (Grenier, 1992; Kinder \& Holt, 1989; Kolenbrander \& Andersen, 1989). This results in the attachment of secondary colonizers to already adhered cells. Co-adhesion is driven by specific receptor-ligand 
interactions that allow new bacterial colonizers to adhere to the previously attached cells and results in increased complexity of the microbial community (Grenier, 1992; Kinder \& Holt, 1989; Kolenbrander \& Andersen, 1989).

At this stage, the microcolonies begin to produce an extracellular matrix comprised of extracellular carbohydrates and genomic DNA. The microcolonies continue to proliferate and develop into 'mature biofilms' that are characterized by vertical growth on the solid surface. The mature biofilm is a complex structure comprised of towering microcolonies interspersed with fluid filled channels, which provide nutrients and oxygen that are required for normal bacterial growth. The channels are also conduits that facilitate the outward movement of bacterial metabolites, waste products, and enzymes.

This biofilm life cycle is completed by the release of the bacterial cells back into the 'planktonic' state either by an 'active' or 'passive' process, known as detachment. In the active process, the cell itself may produce enzymes that cleave the matrix, reducing the integrity of the matrix and facilitating the release of cells. Alternatively, cells in the biofilm may stop production of enzymes that produce the matrix. Thus the biofilm may become exposed and disintegrates. In addition, 'passive' processes may also lead to the release of bacterial cells into a free floating state, which can then recolonize a new surface. For example, the physical abrasion of the tongue against the tooth may facilitate biofilm removal. During the process of biofilm formation, quorum sensing and other signal transduction pathways play an important role in biofilm growth and maturation. For example, the process by which bacterial cells adhere and interact with a 
surface can initiate new genetic programs, allowing the microorganism to survive in the new environment (Blango \& Mulvey, 2009). This is called 'contactdependent signaling'. Contact dependent signaling can also occur between two different organisms. This interspecies adherence can stimulate new genetic programs that allow cells to alter their genetic profiles to enhance viability in the microbial community (Blango \& Mulvey, 2009).

\section{Significance of Etiology of Periodontitis}

Some of the bacteria that contribute to the oral microbiotic community include Porphyromonas gingivalis, Tannerella forsythia, and Treponema denticola (Suzuki et al, 2013). These species are considered 'periodontopathogens', and are classified as 'red' complex oral bacteria that have a strong association with each other and with diseased sites in chronic adult periodontitis (Darveau et al, 2012; Suzuki et al., 2013). Two main hypotheses may explain the role of plaque bacteria in a diseased individual. The "Specific Plaque Hypothesis" asserts that only specific species are involved in causation of disease, even if present in low abundance (Hajishengallis, 2014; Hajishengallis \& Lamont, 2012; Loesche, 1992; Rosier et al, 2014). One of the 'red complex' bacteria, $P$. gingivalis, has been described to function as a keystone pathogen (Hajishengallis \& Lamont, 2012; Rocas et al., 2001; Rosier et al., 2014). It disrupts host-microbe homeostasis in the oral cavity leading to dysbiosis even in low abundance, and is thus strongly associated with adult periodontitis (Hajishengallis \& Lamont, 2012). Given this impact at low abundance, it is believed that $P$. gingivalis alters the host response 
and induces changes in microbial biofilm populations, prompting uncontrolled inflammation and tissue damage (Darveau, 2010; Hajishengallis \& Lamont, 2012; Loesche, 1992). However, this hypothesis cannot completely explain the absence of presumed pathogens in some diseased individuals or the presence of these pathogenic organisms in healthy patients (Darveau, 2010). Contrary to this, the "Non-Specific Plaque Hypothesis" proposes that periodontitis is a result of the overall interaction of the plaque microflora with the host (Hajishengallis \& Lamont, 2012; Rosier et al., 2014). It is well established that plaque-mediated diseases have a multi-factorial etiology and a variety of organisms are involved in its progression (Hajishengallis \& Lamont, 2012; Rosier et al., 2014). Considering both theories, a modified hypothesis has been proposed suggesting that changes in environmental factors lead to a shift in the resident microflora resulting in microbial dysbiosis (Rosier et al., 2014). This modified hypothesis supports the occurrence of potentially pathogenic species as minor members of the resident plaque microflora (Rosier et al., 2014). Certain low-abundance microbial pathogens can cause inflammatory disease by interfering with the host immune system and remodeling the microbiota (Hajishengallis \& Lamont, 2012; Rosier et al., 2014). In healthy individuals, these organisms would be weakly competitive and significantly suppressed by intermicrobial antagonism (Hajishengallis \& Lamont, 2012; Rosier et al., 2014). As such, they would comprise only a small percentage of the plaque microflora and would have limited clinical significance (Rosier et al., 2014). 


\section{$\underline{P .}$ gingivalis and its interaction pattern}

Apart from being considered a keystone pathogen, $P$. gingivalis has long been associated with periodontitis, has a well-characterized population structure, and demonstrates the "easiest" growth and genetic manipulation of the three "red complex' bacteria (Rocas et al., 2001). Due to these factors, $P$. gingivalis has garnered much attention and has been well-studied (Curtis et al., 2011; Darveau et al., 2012; Lamont \& Jenkinson, 1998). P. gingivalis is a pathogen whose primary niche is in the anaerobic environment of subgingival dental plaque; however, initial colonization occurs on supragingival surfaces that already support robust biofilm communities in oral cavity (Daep et al., 2006). Studies suggest that biofilm formation occurs subsequent to initial adherence of $P$. gingivalis to $S$. gordonii cells deposited on the salivary pellicle (Cook et al., 1998). The interaction between $P$. gingivalis and $S$. gordonii is one of the many critical interactions which promote biofilm formation. Targeting this particular interaction may inhibit the biofilm formation more effectively, if not completely. The commensal species S. gordonii provide an attachment substrate for colonization and biofilm accretion by the potential pathogen, $P$. gingivalis (Cook et al., 1998). Due to this favorable interaction, P. gingivalis, has been shown to specifically adhere to primary colonizing bacteria such as S. gordonii (Park et al., 2005). Considering this, the initial colonizing mechanism of $P$. gingivalis is a primary target to inhibit biofilm formation with rationally designed therapeutics that prevent initial supragingival colonization (Daep et al., 2006). 


\section{BAR Peptide}

P. gingivalis is a leading pathogen implicated in chronic adult periodontitis

(Koziel et al., 2014). Previous studies have shown that $P$. gingivalis adheres to $S$. gordonii through the interaction of the minor fimbrial antigen, Mfa1, with a specific region of the streptococcal SspB polypeptide which has been designated BAR (SspB Adhering Region) (Chung et al., 2000; Daep et al., 2006; Daep et al., 2008; Demuth et al., 2001; Lamont et al., 2002). It has been shown that a synthetic peptide comprising the BAR sequence potently inhibits $P$. gingivalis adherence to $S$. gordonii (IC $\left.\mathrm{C}_{50}=1.3 \mu \mathrm{M}\right)$ (Daep et al., 2006; Daep et al., 2008; Daep et al., 2011). Moreover, BAR peptide significantly reduced $P$. gingivalis virulence in mice that harbor $S$. gordonii when administered simultaneously with P. gingivalis cells (Daep et al., 2011). However, the effects of BAR administration demonstrated transient effects, and exhibited weaker potency against preexisting or more complex biofilms. In more complex biofilms, the $\mathrm{IC}_{50}$ increased to $3.6 \mu \mathrm{M}$ and an exposure time of more than 60 minutes was required to achieve equivalent effects as achieved in two species biofilms (Demuth, unpublished). These limitations to clinical translation spurred the need to develop novel approaches to deliver BAR peptide at higher localized concentrations to increase efficacy. Our recent studies suggested that poly (lactic-co-glycolic acid) (PLGA) nanoparticles (NPs) that are surface-functionalized with BAR inhibit $P$. gingivalis and S. gordonii interactions more potently than free soluble peptide (SteinbachRankins and Demuth, unpublished). 


\section{Advantages of Nanoparticles as advanced therapeutics}

Nanoparticles are being studied extensively as a delivery method for antimicrobials for various diseases (De Jong \& Borm, 2008; McMillan, Batrakova et al., 2011; Singh \& Lillard, 2009). They offer many advantages over conventional therapeutic approaches that deliver free antimicrobials via oral, submucosal, or localized delivery routes (Gelperina et al., 2005; Ikuma et al., 2015; Singh \& Lillard, 2009). First, due to their small size, NPs can penetrate barriers to deliver higher concentrations of active agents at target sites, providing increased efficacy (Mudshinge et al. , 2011; Singh \& Lillard, 2009). Second, NPs can be tailored to recognize specific cell types simply by altering their surfacechemistry (Mudshinge et al., 2011; Singh \& Lillard, 2009). Moreover, NPs allow for prolonged delivery of drugs which helps to increase the efficacy of the drugs for increased durations under often adverse physiological conditions in vivo (Hong et al., 2007; Puglia et al., 2008; Singh \& Lillard, 2009). Also, NPs may promote multivalent binding which can act to increase the potency of active agents (Hong et al., 2007). In addition to this, NPs promote the stability of active agents in vivo, by protecting the agent from degradation. Apart from these advantages, NPs can carry a diversity of hydrophilic and hydrophobic active agents (e.g. drugs, proteins, peptides, genes, etc.) that can be co-incorporated in the NP matrix and can be administered orally, locally and intravenously (Mody et al., 2010; Mudshinge et al., 2011; Singh \& Lillard, 2009)

\section{Nanoparticle Types}


NPs have been developed using a variety of materials including metals, ceramics and polymers (Abiodun-Solanke et al., 2014; Adeyemi \& Sulaiman, 2015; De Jong \& Borm, 2008; Wang \& Wang, 2014). Silver NPs have been widely used in dentistry to fabricate new materials like cements or resins (Arvizo et al., 2012; Batra \& Miglani; Ge et al., 2014; Batra et al. 2016). Magnetic NPs like magnetite and maghemite, which are comprised of iron oxide, have been actively studied for cancer and gene therapy applications (Gobbo et al., 2015; Herranz et al., 2011; Batra et al. 2016, unpublished). Copper, zinc, titanium dioxide and quaternary ammonia NPs have demonstrated antimicrobial activity and their hydrophobic nature and surface charge add to their antimicrobial activity (Batra et al. 2016, unpublished). Many of the metal-based NPs have imparted antimicrobial properties that have proven beneficial to oral health by improving the interaction of therapeutics with bacterial biofilms and inhibiting the biofilm formation (Allaker, 2010; Senior et al., 2012; Sirelkhatim et al., 2015; Batra et al., 2016). The proposed mechanism of these antibacterial activities is believed to arise from an electrostatic attraction of positively-charged NPs with the negative charge of the bacterial cell membrane (Palza, 2015; Singh \& Lillard, 2009). Other novel systems using silica NPs and nitric oxide NPs are being studied for to prevent biofilms as well (Kafshgari et al., 2014; Batra et al. 2016). However, despite these attributes, there have been several concerns regarding the toxicity associated with the metallic NPs and their accumulation in various tissues and organs (Niazi \& Gu, 2009). To avert the toxicity associated with metal 
NPs, polymeric NPs have the potential to offer a safer and more biocompatible delivery method.

\section{Polymeric NPs}

Polymeric NPs have demonstrated biocompatibility and flexible tuning of physical properties enabling the drug release and dosage profiles. There are many types

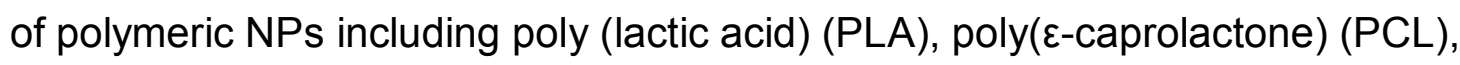
polyethyleneimine, poly (lactic-co-glycolic acid) (PLGA) and poly (glycolic acid) (PGA). These polymers have been extensively used to prevent oral biofilms due to their biodegradability and biocompatibility (Allaker, 2010; Wang et al., 2016). Furthermore, polymeric NPs comprised of PLA and PGA, have the ability to degrade into relatively inert metabolic by-products, enabling safe and non-toxic delivery of associated cargo.

\section{$\underline{\text { PLGA Nanoparticles }}$}

PLGA NPs have been FDA-approved for use in human therapy which is one of the primary reasons for extensive research using these particles (Makadia \& Siegel, 2011). PLGA can deliver hydrophilic and hydrophobic small molecules as well as larger macromolecules due to its well described formulation protocols (Martin-Banderas et al., 2013). PLGA NPs are being tested for use in photodynamic therapy, which when introduced into a bacterial cell, release singlet oxygen and free radicals to destroy bacterial cells (Li \& Huh, 2014). In other work, PLGA NPs that encapsulate methylene blue have demonstrated 
efficacy against Gram-positive as well as Gram-negative bacteria associated with endodontic as well as periodontal infections (Klepac-Ceraj et al., 2011). In addition to the attributes that encapsulation provides, PLGA NPs can be surfacemodified to provide specific targeting and enhanced therapeutic outcomes (Makadia \& Siegel, 2011). Advanced studies are still being done to impart knowledge about the basic functionality of the PLGA NPs with various peptide modifications, yet these are considered to be promising antimicrobials delivery vehicles relative to less specifically-acting conventional therapeutics (Makadia \& Siegel, 2011).

Our preliminary studies have suggested that PLGA NPs that are surfacemodified with BAR peptide increase the effectiveness of peptide-mediated inhibition of $P$. gingivalis-S. gordonii adherence. A possible mechanism by which these NPs enhance the potency is by promoting a multivalent binding interface to increase the avidity of BAR with $P$. gingivalis, or by delivering BAR at a higher localized concentration to $P$. gingivalis. In fact, many studies have demonstrated that multivalent interactions are more efficacious in increasing the avidity of peptides relative to monovalent interactions (Figure 2) ( Wang et al., 2016). In one study, a specific special multivalent effect was observed for polymeric NPs displaying galactan, resulting in a significant increase in binding, relative to free glycan (Bonduelle et al., 2016). In another study, multivalent targeting approach was shown to have the potential to amplify AT1R (Angiotensin 1 Receptor) blockade in the eye and concomitantly deliver a therapeutic payload into ocular lesions choroidal vasculature (Hennig et al., 2015). Similar to these studies, we 
expect that the increase in potency of the surface modified NPs may be due to the increase in the valency.

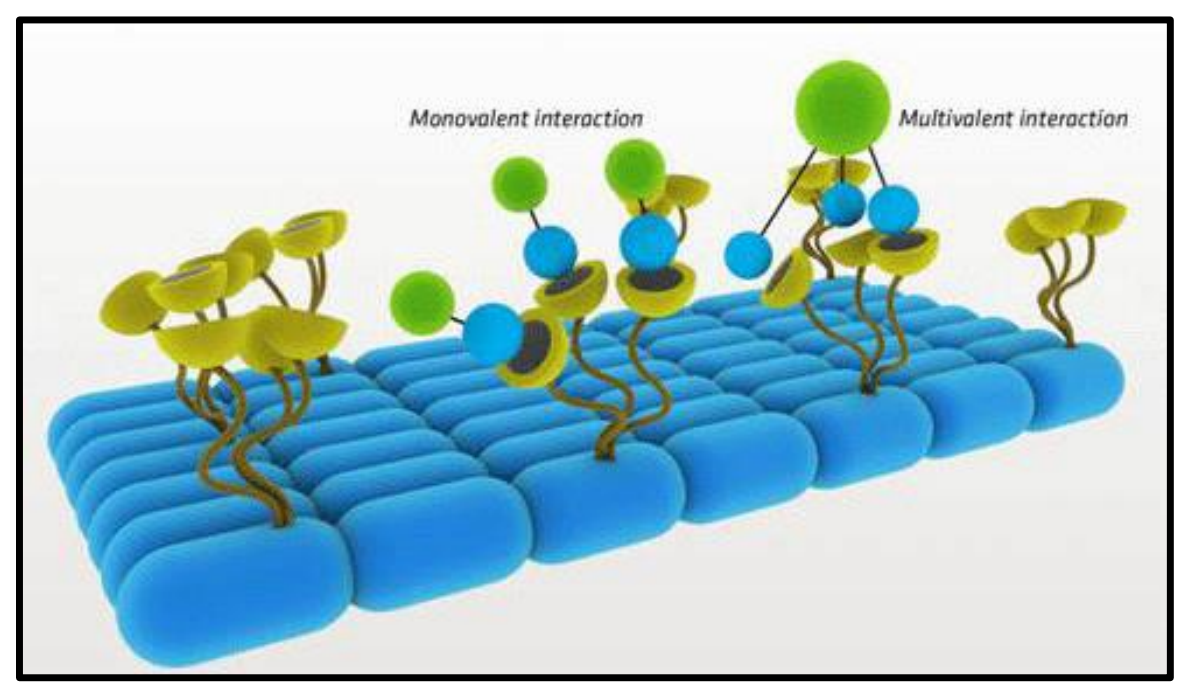

Figure 2 Comparison of monovalent and multivalent interactions. Multivalent interactions are considerably stronger than the individual bonding of a corresponding number of monovalent ligands to a multivalent receptor and are often used in biological systems. Adapted from Prof. Dr. Rainer Haag research topics.

\section{Drug delivery by binding to Immunoglobulins}

Therapeutic drugs and proteins often suffer from short half-life; mainly due to their small size or rapid clearance by enzymes. Genetic modification of these drugs or proteins employing various techniques can improve the pharmacokinetics by prolonging the half-life by either preventing excretion or degradation in the body. Like albumin, certain immunoglobulins $\lg G 1, \lg G 2$ and IgG4 also bind to the FcRn (neonatal Fc receptor) and thus have a long half-life (Strohl, 2015). Similar to the fusion of albumin binding moieties, lgG binding domains (IgBDs) can be fused to therapeutic proteins. Studies have shown 
different IgBDs have different affinity for serum immunoglobulins resulting in different half-lives. The longest half-life of 21 to 23 hours has been seen with the C3 domain from Streptococcal Protein G (SPG-C3) when fused to recombinant antibodies (Kontermann, 2016).

Various types of Fusion Proteins (Genetic fusion to Immunoglobulins) In addition to evaluating multivalent NPs for the delivery of BAR peptide, we designed antibody-fused peptides to evaluate the effect of BAR valency. The antibodies acted as another carrier for the peptide. Relative to NPs, BAR fusion proteins offer the attributes of smaller size and definitive conjugation, allowing us to easily assess the impact of valency on increased binding and corresponding potency. This fusion protein allows us to begin to assess the degree of valency that is required to increase potency of the peptide to inhibit biofilms. Fusion of proteins to the Fc region of $\lg G 1,2$ and 4 will impart longer half-lives due to binding of FcRn (neonatal Fc Receptor) to Fc region and FcRn mediated recycling. Examples of Fc fusion proteins include TNF receptor 2 (etanercept), VEGF (vascular endothelial growth factor) receptor (aflibercept), IL-1 receptor (rilonacept), CTLA-4 (cytotoxic T-lymphocyte-associated protein 4) (abatacept, belatacept) and others (Strohl, 2015). Etanercept was the first approved Fc fusion protein. Fc fusion is also used to extend the half-lives of biologically active proteins. Romiplostim, a thrombopoetin mimetic Peptide-Fc fusion protein is approved for treating immune thrombocytopenia (Kontermann, 2016). Alprolix (Factor IX-Fc), a monomeric Fc fusion molecule, showed a terminal half-life of 57-83 hours which was approximately three times more than the half-life of other 
formulations of Factor IX (Strohl, 2015). These fusion proteins and various others like Dulaglutide (GLP-1-Fc fusion protein), Efraloctocog- $\alpha$ (Factor VIII fused to IgG1 Fc), Corifollitropin- $\alpha$ (FSH-CTP fusion) have been approved for marketing (Strohl, 2015). Broadly neutralizing monoclonal antibodies (bnMAbs) may offer powerful tools as topical microbicides (Hamorsky et al., 2013). However, this option is hampered due to expensive MAb bio manufacturing based on mammalian cell culture. To address this issue, a new production system for bnMAb VRC01 in Nicotiana benthamiana plants using a tobamovirus replicon vector was developed (Hamorsky et al., 2013). Also, the production of antibodies using the conventional IgG production is not very safe. This novel plant based production system is being used for our experiments and employs a simple manufacturing process, as opposed to the conventional system which utilizes two separate vectors for $\mathrm{H}$ and $\mathrm{L}$ chain (Hamorsky et al., 2013). This provides a more consistent and a stable production as it generated antibodies from a single polypeptide (Hamorsky et al., 2013). We will use an IgG antibody fused to the BAR peptide to test the inhibition of interaction between $P$. gingivalis and $S$. gordonii and compare it with the soluble BAR peptide. In addition to the small size of the Ab as compared with the NPs, another reason for us to use it in our experiments is because it would allow us to be able to compare the number of BAR molecules on the NPs of the lowest BAR concentration $(8.9 \mu \mathrm{g} / \mathrm{mg} \mathrm{NPs})$ to the number of BAR molecules ( 2 or 4 ) on the BAR-Fc fusion. It would help us to determine whether or not there is a particular number of BAR molecules required to show an increase in potency. 


\section{CHAPTER 2}

\section{HYPOTHESIS AND SPECIFIC AIMS}

Our overall HYPOTHESIS is that BAR-NPs may interact with $P$. gingivalis with higher valency than free soluble peptide, thereby increasing the avidity and potency of the interaction. This hypothesis will be tested using two approaches. The first will utilize BAR-modified NPs which can be functionalized with a high peptide valency. The second approach will examine BAR-antibody fusions with lower and more well-defined peptide valency. The Specific Aims are to:

\section{SPECIFIC AIMS}

1) Construct BAR-modified PLGA nanoparticles and determine whether NPs promote multivalent interaction with $P$. gingivalis.

2) Construct BAR-antibody fusion proteins in dimer and tetramer forms and determine if they function as more potent inhibitors of $P$. gingivalis adherence relative to free peptide 


\section{CHAPTER 3}

\section{MATERIALS AND METHODS}

\section{Peptide Synthesis}

The peptide containing a covalently attached biotin at its $\mathrm{N}$-terminus was synthesized by BioSynthesis, Inc. (Lewisville, TX) and was obtained with greater than $85 \%$ purity. The peptide is comprised of residues 1167 to 1193 of the SspB (Antigen I/II) protein sequence of S. gordonii. The BAR-Flc (Fluorescent BAR peptide) and unlabeled biotin BAR peptide used in this study, is shown in Table 1. Both contain biotin (BTN) attached to the $\mathrm{N}$-Terminus and were obtained in lyophilized form.

Table 1 Sequence of BAR peptide.

\begin{tabular}{|l|l|}
\hline Peptide Name & Peptide Sequence \\
\hline BAR-Flc & $\begin{array}{l}\text { ( BTN )-LEAAPK-Kflc-VQDLLKKANITVKGAFQLFS- } \\
\text { OH }\end{array}$ \\
\hline BAR & ( BTN )-LEAAPKKKVQDLLKKANITVKGAFQLFS-OH \\
\hline
\end{tabular}

To determine the amount of BAR peptide on the NP surface, we used the fluorescent BAR peptide (BAR-Flc) which is synthesized by covalently attaching 
6-carboxyfluorescein (FIc) to the epsilon amine of the lysine residue that is underlined in Table 1.

\section{Growth of Bacterial Strains}

P. gingivalis strain ATCC 33277 was grown in Trypticase soy broth (TSBY medium) (Difco) supplemented with $0.5 \%(\mathrm{w} / \mathrm{v})$ yeast extract, $1 \mu \mathrm{g} / \mathrm{ml}$ (final concentration) menadione, and $5 \mu \mathrm{g} / \mathrm{ml}$ (final concentration) hemin. Twenty milliliters of media was reduced for 24 hours under anaerobic conditions consisting of $10 \% \mathrm{CO}_{2}, 10 \% \mathrm{H}_{2}$, and $80 \% \mathrm{~N}_{2}$. Next, $P$. gingivalis was inoculated into the medium and grown for 48 hours at $37^{\circ} \mathrm{C}$ under anaerobic conditions. $S$. gordonii DL-1 was cultured aerobically without shaking in brain-heart infusion (BHI) broth supplemented with $1 \%$ yeast extract for 16 hours at $37^{\circ} \mathrm{C}$.

\section{Avidin-Palmitic Acid Conjugation}

To obtain BAR-modified PLGA NPs, the NP surfaces were modified with avidin palmitate to subsequently attach biotinylated BAR. Avidin-palmitate was conjugated as described by Fahmy and Saltzman (Fahmy et al., 2005). Briefly, $10 \mathrm{mg}$ of avidin was dissolved in $1.2 \mathrm{ml}$ of $2 \%$ sodium deoxycholate $(\mathrm{NaDC})$ in phosphate buffered saline (PBS) warmed to $37^{\circ} \mathrm{C}$. Palmitic acid-NHS (PA-NHS, Sigma) was dissolved in $2 \% \mathrm{NaDC}$ at $1 \mathrm{mg} / \mathrm{ml}$ and sonicated until well-mixed. Eight hundred microliters of the $1 \mathrm{mg} / \mathrm{ml}$ PA-NHS (PA-N-hydroxysuccinamide ester, Sigma) solution was added dropwise to the reaction vial, and reacted overnight at $37^{\circ} \mathrm{C}$. The following day, the reaction was dialyzed in $1200 \mathrm{ml}$ of 
$0.15 \% \mathrm{NaDC}$ in PBS heated to $37^{\circ} \mathrm{C}$ with $3500 \mathrm{MWCO}$ dialysis tubing to remove free PA-NHS. The solution was dialyzed overnight at $37^{\circ} \mathrm{C}$, and dialysis cassette contents were transferred to a storage vial and stored at $4{ }^{\circ} \mathrm{C}$. Two milliliters of the above made PA-NHS solution was added dropwise to the reaction vial containing avidin, and reacted overnight at $37^{\circ} \mathrm{C}$. The following day, the reaction was dialyzed in $1.2 \mathrm{~L}$ of $0.15 \%(\mathrm{w} / \mathrm{v}) \mathrm{NaDC}$ in PBS. This dialysis sink solution was heated to $37^{\circ} \mathrm{C}$, and a 3500 molecular weight cut off (MWCO) dialysis tube was used to remove free PA-NHS. After overnight dialysis at $37^{\circ} \mathrm{C}$, complexed avidinpalmitate was transferred to a storage vial from the dialysis cassette and stored at $4^{\circ} \mathrm{C}$.

\section{Nanoparticle Synthesis}

Surface-modified avidin NPs were made using the oil-in-water (o/w) single emulsion technique. On the first day, two $100 \mathrm{mg}$ PLGA NP batches were each dissolved in $2 \mathrm{ml} \mathrm{DCM}$ overnight. The next day, $2 \mathrm{ml}$ of $5 \%(\mathrm{w} / \mathrm{v})$ polyvinyl alcohol (PVA) was mixed with $2 \mathrm{ml}$ of $5 \mathrm{mg} / \mathrm{ml}$ avidin-palmitate and vortexed slowly. PLGA-DCM solution was subsequently added dropwise to two tubes that contained the previously mixed PVA-Avidin-Palmitate $(4 \mathrm{ml})$ while vortexed at slow speed, with subsequent ultrasonication (Figure 3). 


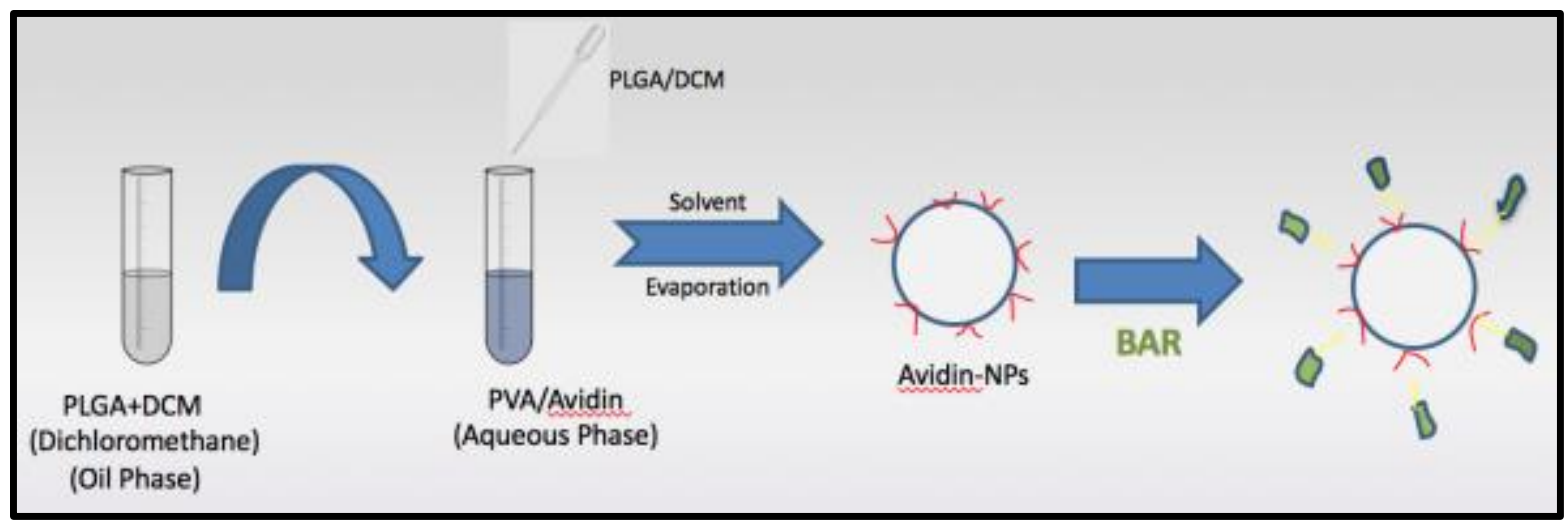

Figure 3 Oil-in-water single emulsion technique.

The DCM solvent was evaporated by adding the NP solution dropwise to $50 \mathrm{ml}$ of 0.3\% PVA and mixed for 3 hours. After evaporation, the solution was divided between six tubes and centrifuged at $13,000 \mathrm{rpm}$ for 10 minutes at $4^{\circ} \mathrm{C}$ to wash the NPs prior to peptide conjugation. The supernatant was discarded and the pellet was suspended in $10 \mathrm{ml}$ PBS. Each of the four tubes was incubated with 1 $\mathrm{ml}$ of BAR-Flc each at a different concentration for 1 hour. The concentrations used were 8.9, 17.8, 35.5, 71, 142 and $284 \mu \mathrm{g}$ BAR/mg NPs, dissolved in $1 \mathrm{ml}$ PBS, for a total of $10 \mathrm{ml}$ reaction volume. After the reaction, NPs were transferred to centrifuge tubes, washed with $20 \mathrm{ml}$ PBS and centrifuged again. The NPs were then suspended with $20 \mathrm{ml}$ DI water and washed three times to remove unbound peptide. After three washes, the NPs were suspended in $5 \mathrm{ml}$ of distilled water, transferred to a $10 \mathrm{ml}$ cryotube, frozen in $-80^{\circ} \mathrm{C}$ for 3 hours and subsequently lyophilized. All NPs were stored at $-20^{\circ} \mathrm{C}$ after synthesis. The surface-modified particles with unlabeled non-fluorescent BAR peptide were synthesized similarly. 


\section{Synthesis of BAR-Fc Fusion Protein}

A gene fusion protein encoding the desired $A b$ fused to BAR was synthesized. A chimeric rabbit human monoclonal antibody sequence was used that was designed and constructed by Dr. Palmer's team in the Owensboro Cancer Research Program. A BAR-Fc fusion dimer (Fc) (Figure 4) was constructed in which a signal peptide was fused to the BAR peptide, then fused to the $\lg \mathrm{G} 1$ hinge and Fc region. The signal peptide is a naturally occurring secretion signal that are meant to be transported out from the cells. Once it is secreted, the protein is easy to purify. The hinge serves as a flexible spacer between the two parts of the Fc fusion protein, allowing each part of the molecule to function independently. Utilizing these motifs, enabled alterations in the fusion protein valency. Human IgG1 displays high ADCC (Antibody-dependent cell-mediated toxicity) and CDC (Complement dependent toxicity), and is the most suitable for therapeutic use against pathogens and cancer cells.

For the dimer molecule, each Fc protein has two BAR peptide molecules attached to it. In the case of the tetramer (Fc') (Figure 5), the signal peptide fused to the BAR peptide was additionally fused to both the light chain and heavy chain in place of the rabbit $\mathrm{VL}$ and $\mathrm{VH}$ sequences, resulting in a valency of four peptides conjugated to each Fc' molecule.

The gene was delivered via the Tobamoviral vector into Nicotiana benthamiana leaves. The leaf material, 5-7 days post-infiltration, was homogenized and the protein was extracted and purified. Host kex $2 p$ protease was used for cleavage to produce the antibodies in $N$. benthamiana plants. 


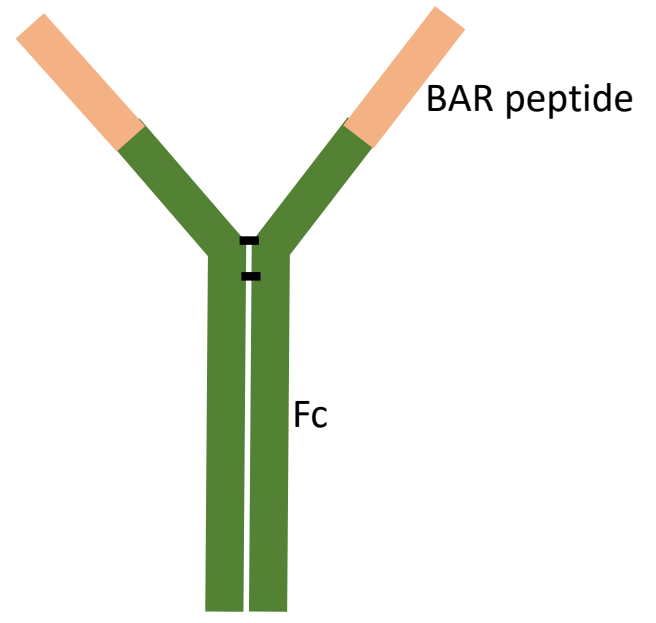

Dimer Sequence:

MGKQMAALCGFLLVALLWLTPDVAHG-

LEAAPKKVQDLLKKANITVKGAFQLFS-

DKTHTCPPCPAPELLGGPSVFLFPPKPKDTLMISRT

PEVTCVVVDVSHEDPEVKFNWYVDGVEVHNAKT

KPREEQYNSTYRVVSVLTVLHQDWLNGKEYKCKV

SNKALPAPIEKTISKAKGQPREPQVYTLPPSREEM

TKNQVSLTCLVKGFYPSDIAVEWESNGQPENNYK

TTPPVLDSDGSFFLYSKLTVDKSRWQQGNVFSCS

VMHEALHNHYTQKSLSLSPGK

Figure 4: BAR-Fc fusion dimer $(\mathrm{Fc})$ showing BAR peptide fused to $\mathrm{IgG1}$ hinge and $\mathrm{Fc}$ region. Rice alpha amylase signal peptide (light blue), BAR peptide (light orange), Human IgG1 hinge + Fc (dark green)

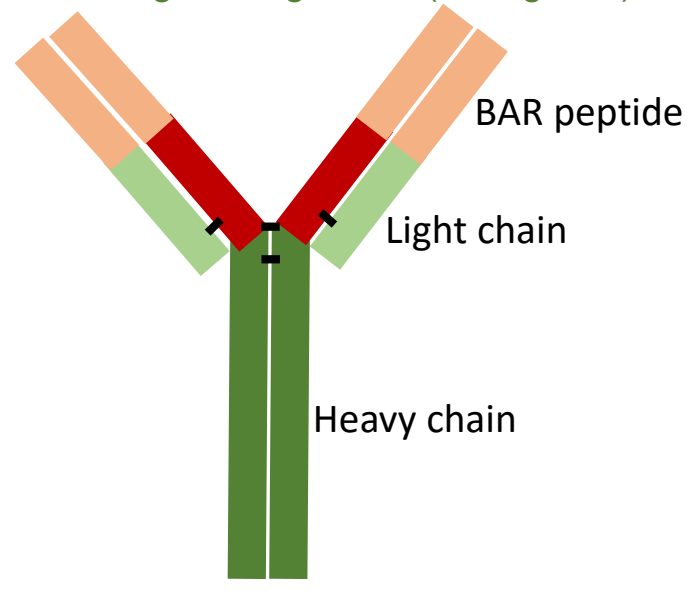

Tetramer Sequence:

MGKQMAALCGFLLVALLWLTPDVAHG-

LEAAPKKVQDLLKKANITVIKGAFQLFS-

RTVAAPSVFIFPPSDEQLLSSGTASVVCLLNNFY

PREAKVQWKVDNALQSGNSQESVTEQDSKD

STYSLSSTLTLSKADYEKHKVYACEVTHQGLRS

PVTKSFNRGECGGKRTIQDSATDTVDLGAELH

OURHOURSDDPPPTASDIGKRGG-

LEAAPKKVVDLLKKANITVKGAFQLFS-

ASTKGPSVFPLAPSSKSTSGGTAALGCLVKDYF PEPVTVSWNSGALTSGVHTFPAVLQSSGLYSL SSVVTVPSSSLGTQTYICNVNHKPSNTKVDKR VEPKSCDKTHTCPPCPAPELLGGPSVFLFPPKPK DTLMISRTPEVTCVVVDVSHEDPEVKFNWYVD GVEVHNAKTKPREEQYNSTYRVVSVLTVLHQD WLNGKEYKCKVSNKALPAPIEKTISKAKGQPRE PQVYTLPPSREEMTKNQVSLTCLVKGFYPSDIA VEWESNGQPENNYKTTPPVLDSDGSFFLYSKLT VDKSRWQQGNVFSCSVMHEALHNHYTQKSLS LSPGK

Figure 5 Fc': BAR-Fc fusion tetramer having a full antibody molecule ( $\left.\mathrm{Fc}^{\prime}\right)$ showing BAR peptide fused to both constant light and constant heavy chain in place of variable light and variable heavy chain. Rice alpha amylase signal peptide (light blue), BAR peptide (light orange), Constant light chain (light green), KP6 propeptide sequence (dark yellow), Constant heavy chain (dark red), Human IgG1 hinge + Fc (dark green). 


\section{Fluorescence Assay}

To measure the amount of BAR peptide that was conjugated to the NP surface, a fluorescent binding assay was conducted. NPs were reacted with BAR-Flc as described above. A $1 \mathrm{mg} / \mathrm{ml}$ solution of NPs in 1X PBS was made and one hundred microliters of the suspension was added to 96-well black microtiter plates in triplicate. The fluorescence was measured at excitation/emissions wavelengths of $485 \mathrm{~nm} / 535 \mathrm{~nm}$, and the background fluorescence was subtracted from the final fluorescence readings. The level of BAR associated with the NP samples was determined by comparing fluorescence with a standard curve of BAR-Flc. To obtain the standard curve of BAR-Flc, a serial dilution of 1 $\mathrm{mg} / \mathrm{ml} \mathrm{BAR-FLC} \mathrm{stock} \mathrm{was} \mathrm{mixed} \mathrm{with} \mathrm{buffer} \mathrm{to} \mathrm{generate} \mathrm{a} \mathrm{range} \mathrm{of} \mathrm{peptide}$ concentrations from 0.01 to $100 \mu \mathrm{g}$ BAR peptide per $\mathrm{ml}$.

\section{Dual Species Biofilm Assay}

\section{Testing NP-BAR Inhibition}

Cultures of $P$. gingivalis and $S$. gordonii were obtained as previously described. S. gordonii DL-1 cells were harvested by centrifuging a $19 \mathrm{ml}$ culture of $S$. gordonii at $5600 \mathrm{rpm}$ for $15 \mathrm{~min}$. One milliliter was used to measure the initial O.D. (optical density) of cells. The supernatant was discarded and the cell pellet was suspended in $1 \mathrm{ml}$ of 1 X PBS. S. gordonii was labeled with $40 \mu \mathrm{l}$ of $5 \mathrm{mg} / \mathrm{ml}$ hexidium iodide (Molecular Probes, Eugene, OR) and incubated for $15 \mathrm{~min}$ at room temperature on a rocker platform protected from light. After incubation, the labeled samples were centrifuged at 10,000 rpm for 3 mins, the supernatant was 
discarded, and the cells were suspended in $1 \mathrm{ml}$ of $1 \mathrm{X}$ PBS. Following this, the O.D. was measured at $600 \mathrm{~nm}$ from twenty-fold diluted cultures of $S$. gordonii to determine cell count. For all experiments, the optical density of $S$. gordonii cells was adjusted to 0.8 for uniformity of the $S$. gordonii cell counts in each well. After adjusting the optical density, $1 \mathrm{ml}$ of $S$. gordonii cells was added to each well of five 12-well culture plates containing a sterilized micro-coverslip. The cell culture plates were wrapped in aluminum foil to protect the labeled cells from light and placed on a rocker platform in the anaerobic chamber for 24 hours.

P. gingivalis cultures used for biofilm formation were optimized using a similar approach. In short, $19 \mathrm{ml}$ of $P$. gingivalis cells were centrifuged for $15 \mathrm{~min}$ at $5600 \mathrm{rpm}$ and $1 \mathrm{ml}$ was used to measure the initial O.D. The supernatant was discarded and the cell pellet was suspended in $1 \mathrm{ml}$ of pre-reduced 1X PBS. $P$. gingivalis cells were labeled with $40 \mu \mathrm{l}$ of $4 \mathrm{mg} / \mathrm{ml}$ carboxyfluoresceinsuccinylester (Molecular Probes). Cells were incubated with the fluorescent dye for 15 mins on a rocker platform and protected from light. Following incubation, cells were centrifuged at $10,000 \mathrm{rpm}$ for $3 \mathrm{~min}$ and the supernatant was discarded to remove the unbound fluorescent dye. The pelleted cells were suspended in $1 \mathrm{ml}$ of pre-reduced $1 \mathrm{X}$ PBS. The optical density of $P$. gingivalis cells was adjusted to 0.4 for uniformity of the $P$. gingivalis cell counts in each well.

For biofilm inhibition experiments, BAR-NPs, soluble BAR or avidin-only NPs were pre-incubated with labeled $P$. gingivalis at $25^{\circ} \mathrm{C}$ for $30 \mathrm{~min}$ before transferring to the appropriate wells. The NPs that were surface-modified with 
unlabeled BAR peptide were used for these experiments. For each batch of NPs that were synthesized, using input concentrations of BAR of $71 \mu \mathrm{g} \mathrm{BAR} / \mathrm{mg}$ NPs, 35.5 $\mu \mathrm{g} \mathrm{BAR/mg} \mathrm{NPs,} 17.8 \mu \mathrm{g}$ BAR/mg NPs, or $8.9 \mu \mathrm{g} \mathrm{BAR/mg} \mathrm{NPs,} \mathrm{five}$ different concentrations of BAR $(0.3 \mu \mathrm{M}, 0.7 \mu \mathrm{M}, 1.3 \mu \mathrm{M}, 2.0 \mu \mathrm{M}, 2.5 \mu \mathrm{M})$ were tested for biofilm inhibition. After calculating the amount of NPs required to deliver the desired level of BAR peptide, one milliliter of each of these solutions was added in triplicate to the culture plates. Molar equivalents of free BAR peptide $(0.3 \mu \mathrm{M}, 0.7 \mu \mathrm{M}, 1.3 \mu \mathrm{M}, 2.0 \mu \mathrm{M}, 2.5 \mu \mathrm{M})$ were also tested. Controls comprised treating cells with PBS alone or with avidin-only NPs in triplicate. The cell culture plates were covered with aluminum foil and incubated for 18-24 hours in an anaerobic chamber.

Following incubation, the supernatant was removed from the wells of the cell culture plates and the cells were washed with pre-reduced 1X PBS to remove non-adherent bacterial cells. The cells were subsequently fixed with $4 \%(\mathrm{w} / \mathrm{v})$ paraformaldehyde, excess paraformaldehyde was removed, and the cells were washed with pre-reduced 1X PBS. After washing, the coverslips were mounted on a glass slide using Prolong Gold anti-fade reagent and viewed using confocal laser scanning microscopy.

\section{Testing BAR-FC Fusion Inhibition}

Biofilm inhibition by the purified BAR-Fc fusion protein was conducted similarly as described above. Three different concentrations of the BAR-Fc fusion protein were tested; $1 \mu \mathrm{M}, 0.5 \mu \mathrm{M}$, and $0.25 \mu \mathrm{M}$, corresponding to $2.0 \mu \mathrm{M}, 1.0 \mu \mathrm{M}$ and 
$0.5 \mu \mathrm{M}$ equivalents of BAR, respectively, since each fusion protein contained two molecules of BAR. Free BAR-peptide (unlabeled) at concentrations of $2.0 \mu \mathrm{M}$, $1.0 \mu \mathrm{M}$ and $0.5 \mu \mathrm{M}$ were tested. Control reactions consisted of treating cells with PBS alone or with antibody that did not contain BAR.

\section{Confocal Microscopy}

P. gingivalis-S. gordonii biofilms were visualized using a Leica Microsystems confocal laser scanning microscope (TCS SP8) and the Leica Application Suite X software. The slides were viewed using an argon laser for visualization of FITClabeled $P$. gingivalis and the HeNe-G laser to visualize hexidium iodide-labeled streptococci. $P$. gingivalis binding was determined from randomly chosen frames using Leica Application Suite X Software. Z-stack images of the biofilms were obtained using a z-step size of $0.7 \mu \mathrm{M}$ and were constructed and analyzed using the Volocity image analysis software.

\section{Image Analysis}

After obtaining biofilm images using confocal microscopy, the resulting z-stack images were processed and reconstructed into 3D images using the Volocity software. Images were imported into Volocity as multiple Tiff-files. Uniform filters were used to remove noise from the images and were further analyzed to quantify the extent of $P$. gingivalis binding. The image brightness and contrast was adjusted equally for all frames, and a snapshot of the image was captured. Next, the ratio of green to red fluorescence was determined. Each peptide 
concentration was analyzed in triplicate and 3 independent frames were measured for each well. The mean and variation (SD) between samples was determined using ANOVA. The variation was considered statistically significant when $\mathrm{P}<0.05$. 


\section{CHAPTER 4}

\section{RESULTS}

\section{Surface Modification Efficacy of PLGA NPs with BAR Peptide}

A fluorescence assay was used to determine the amount of BAR peptide that was bound to the surface of the NPs. Avidin-NPs were titrated with BAR peptide at six different concentrations; 8.9, 17.8, 35.5, 71,142 and $284 \mu \mathrm{g} \mathrm{BAR/mg} \mathrm{NPs.}$ Previous experiments showed that a concentration of $142 \mu \mathrm{g} \mathrm{BAR/mg} \mathrm{NPs} \mathrm{was}$ required to saturate the available avidin binding sites. However, in those experiments $2 \mathrm{ml}$ of $5 \mathrm{mg} / \mathrm{ml}$ avidin was used to modify $50 \mathrm{mg}$ PLGA NPs during synthesis. In the current experiments, $2 \mathrm{ml}$ of $5 \mathrm{mg} / \mathrm{ml}$ avidin was used to modify 100mg PLGA NPs, resulting in half the modification density (per mg NP) used in previous experiments. To measure the degree of modification, NPs were incubated with various concentrations of BAR-Flc for 1 hour, washed, frozen, and lyophilized. Fluorescence was measured as previously described. We observed that the incorporation of BAR-Flc was directly related to the concentration of BAR-Flc added. A standard curve (Figure 6) of soluble BAR-Flc was used to quantify the output concentration of BAR. 


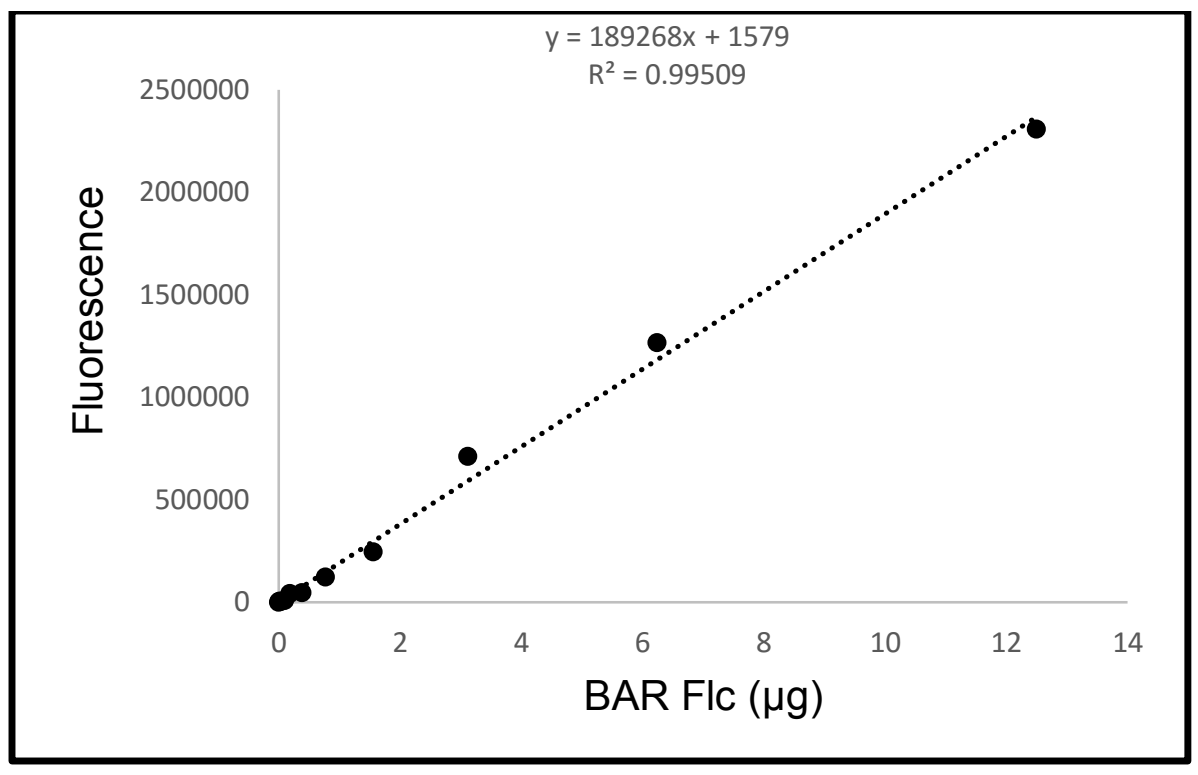

Figure 6 Standard Curve for free BAR peptide showing fluorescence at increasing BAR amounts. This graph was used to calculate the BAR Flc output concentration for the BAR-NPs. The x-axis is expressed in terms of the amount of BAR added per well $(\mu \mathrm{g})$.

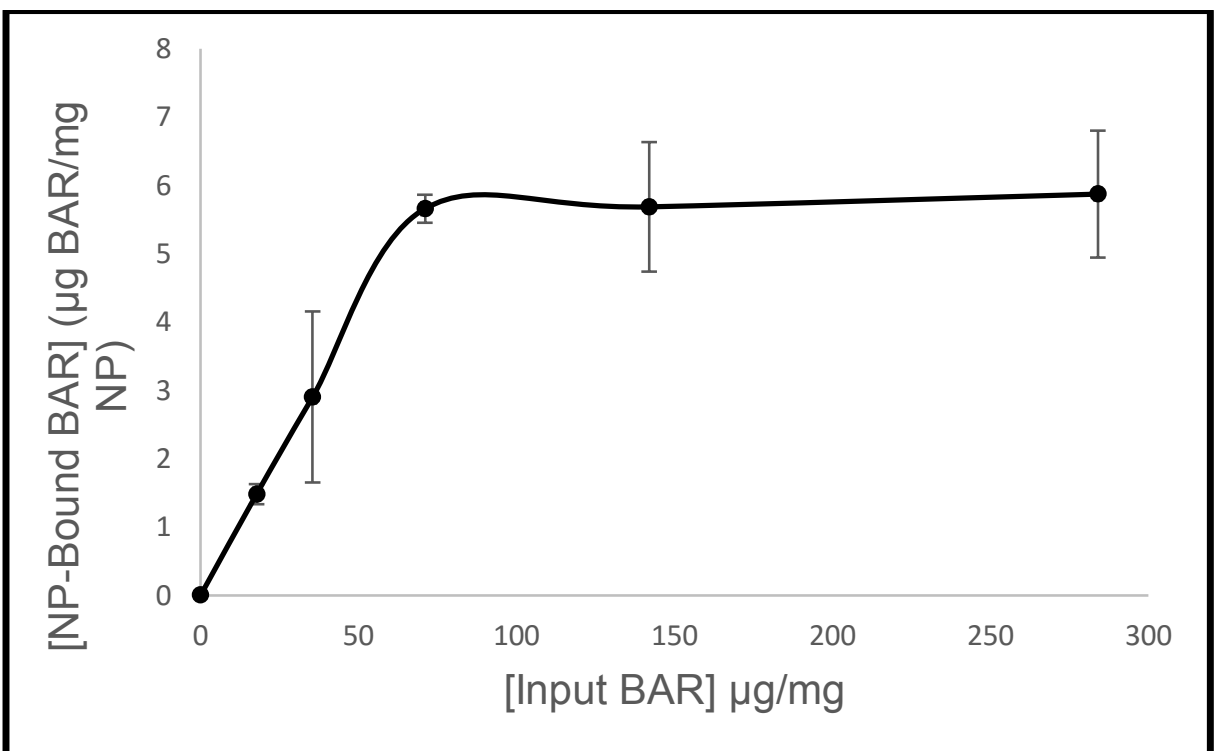

Figure 7 Saturation curve for fluorescently labelled BAR. The input concentration of BAR was varied and resulted in a dose-dependent amount of BAR conjugated to the NP surface ranging from 1.48 to $5.87 \mu \mathrm{g}$ BAR/mg NPs. We observed that above $71 \mu \mathrm{g}$ $\mathrm{BAR} / \mathrm{mg}$ NP (input concentration), the avidin sites on the NP surface were saturated resulting in no additional conjugation to the NP surface. 
As shown in Figure 7 , an input concentration of $71 \mu \mathrm{g} / \mathrm{mg}$ NPs resulted in saturation, indicating that all available avidin binding sites were bound by biotinBAR peptide. Beyond this input concentration, additional peptide was not conjugated to the NP surface.

Table 2 Correlation between the input concentration of BAR-FLC peptide and quantity of BAR-FLC on the NP surface. Increasing amounts of BAR peptide resulted in increased amounts of conjugated BAR. However, above 71 ug BAR/mg NP, the NP surface was saturated as seen in Figure 7.

\begin{tabular}{|c|c|c|}
\hline \multirow{2}{*}{ Sample } & $\begin{array}{c}\text { [Output: } \\
\text { [Input: Quantity of BAR- } \\
\text { with surface of NPs (mg), }\end{array}$ & $\begin{array}{c}\text { Quantity of BAR- } \\
\text { bound to } \\
\text { surface of NPs } \\
\text { (mg), ug/mg] }\end{array}$ \\
\hline A & ug/mg] & $5.87 \pm 0.48$ \\
\hline B & 284 & $5.69 \pm 0.95$ \\
\hline C & 142 & $5.66 \pm 0.20$ \\
\hline D & 71 & $2.90 \pm 0.16$ \\
E & 35.5 & $1.48 \pm 0.17$ \\
\hline F & 17.8 & $1.20 \pm 0.68$ \\
\hline
\end{tabular}

Previous experiments showed incorporation of $1.5 \mathrm{nmol}$ avidin per mg NP. Assuming 4 binding sites per avidin, the maximal payload of BAR is $6 \mathrm{nmol}$ per mg NP ( 22 $\mu \mathrm{g} / \mathrm{mg}$ NP). According to Table 2, after reacting the NP surface with 
71,142 , and $284 \mu \mathrm{g} \mathrm{BAR/mg} \mathrm{NPs,} \mathrm{the} \mathrm{NP} \mathrm{surface} \mathrm{was} \mathrm{saturated} \mathrm{with} \mathrm{BAR}$ peptide, and bound approximately $5.7 \mu \mathrm{g}$ BAR per mg NP. This suggests that $26 \%$ of the avidin binding sites are available for interaction with BAR.

Biofilm Inhibition Assay with BAR-NPs

The biofilm inhibition and fluorescence binding assays were performed in parallel to minimize experimental errors. As previously discussed, different concentrations of BAR-NPs were evaluated to determine the effect of peptide valency on $P$. gingivalis and S. gordonii inhibition. Streptococcal cells were immobilized and $P$. gingivalis was incubated with S. gordonii for 18-24 hours. The biofilms were visualized using confocal microscopy and the percent inhibition was calculated by determining the ratio of $S$. gordonii to $P$. gingivalis cells using Volocity. Previous studies showed that the $\mathrm{IC}_{50}$ (50\% inhibitory concentration) of soluble BAR was $1.3 \mu \mathrm{M}$; therefore, a range of BAR molar equivalents ranging from $0.3-2.5 \mu \mathrm{M}$ was tested for each formulation of BAR-NPs (containing payloads of 1.20, 1.48, 2.90 and $5.66 \mu \mathrm{g} \mathrm{BAR/mg} \mathrm{NP;} \mathrm{see} \mathrm{Table} \mathrm{2).} \mathrm{For} \mathrm{control}$ reactions, $P$. gingivalis was treated with defined concentrations of soluble BAR $(1.3,2.0$, and $2.5 \mu \mathrm{M})$ or avidin-NPs alone. $P$. gingivalis was also incubated with S. gordonii in the presence of buffer alone. The corresponding biofilm images are shown in Figures 8 and 9. 


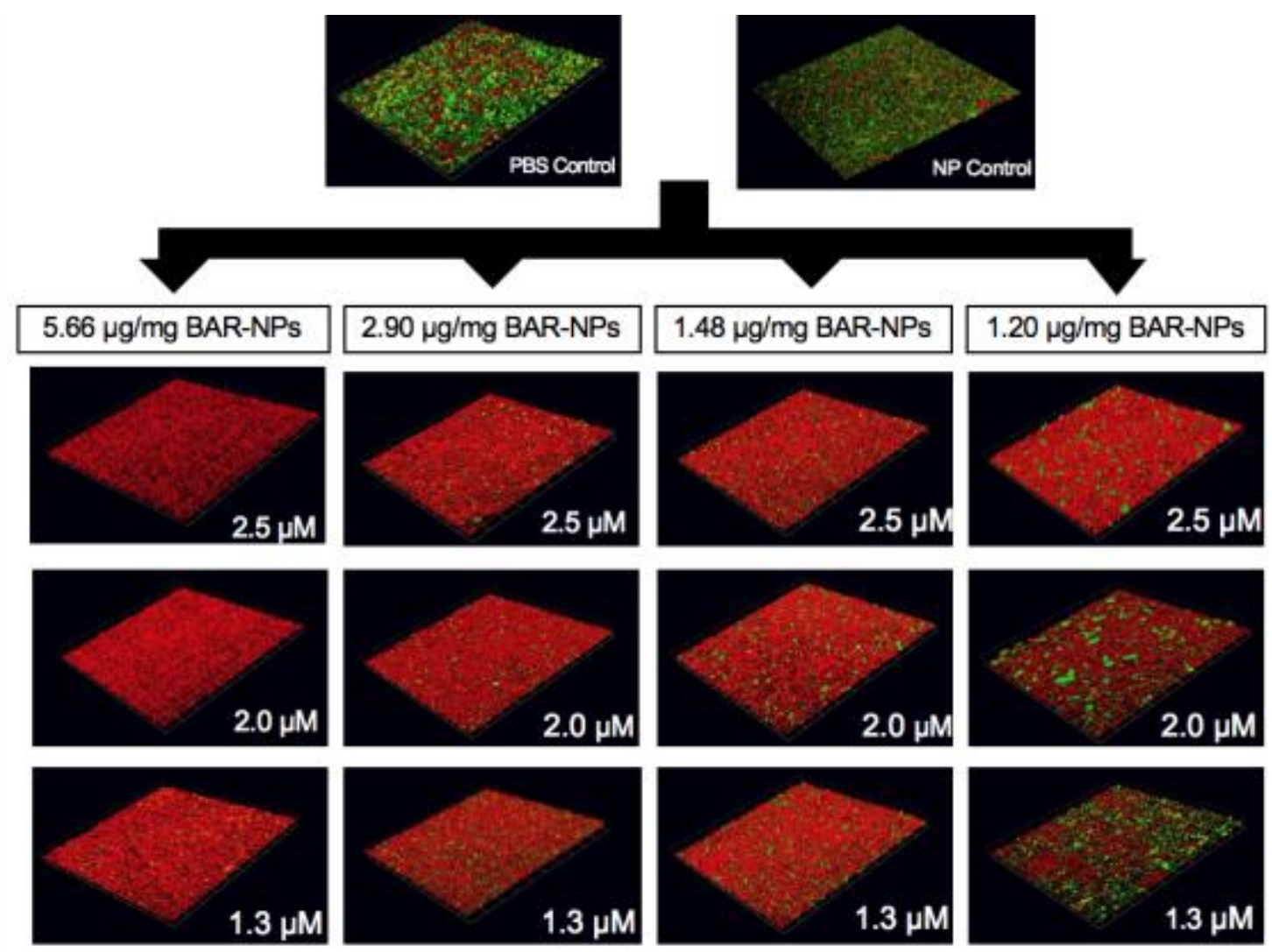

Figure 8: BAR-NP inhibition of $P$. gingivalis (green cells) adherence to $S$. gordonii (red cells). Biofilms were visualized by confocal microscopy and image stacks were assembled using Volocity image analysis software. The concentrations indicated on the images represent BAR peptide equivalents on the NP surface. As the surface density of BAR on the NP surface decreases (left-to-right), a decrease in biofilm inhibition is observed, indicated by the increased presence of $P$. gingivalis cells (green). Similarly, as the molar equivalent of BAR peptide delivered by each NP formulation is decreased (top-to-bottom), we observe a decrease in biofilm inhibition indicated by the increased presence of $P$. gingivalis cells (green). This figure displays molar equivalents of BAR ranging from 2.5 to $1.3 \mu \mathrm{M}$. 


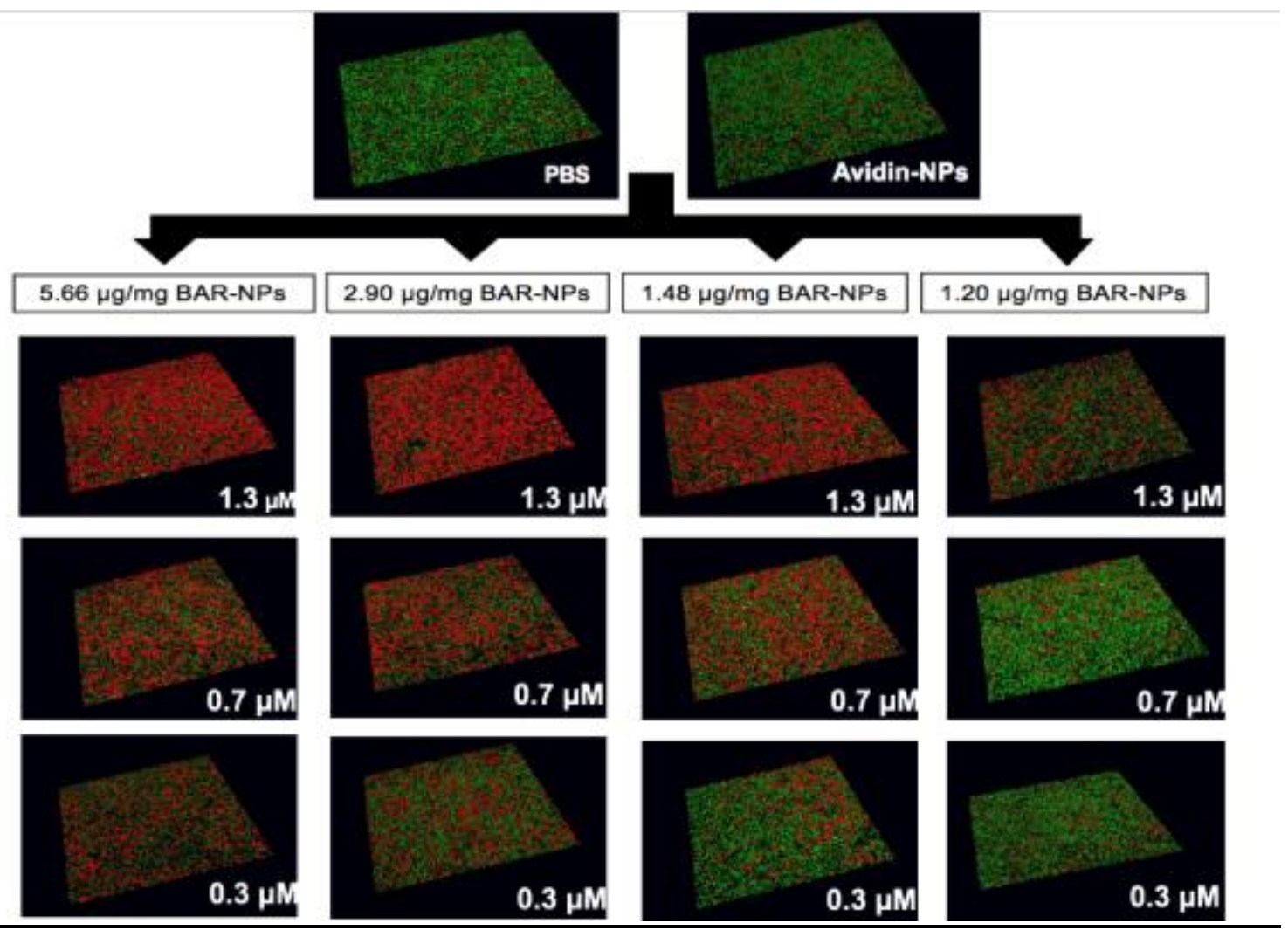

Figure 9: BAR-NP inhibition of $P$. gingivalis (green cells) adherence to $S$. gordonii (red cells). Biofilms were visualized by confocal microscopy and image stacks were assembled using Volocity image analysis software. The concentrations indicated on the images represent BAR peptide equivalents on the NP surface. As the surface density of BAR on the NP surface decreases (left-to-right), a decrease in biofilm inhibition is observed, indicated by the increased presence of $P$. gingivalis cells (green). Similarly, as the molar equivalent of BAR peptide delivered by each NP formulation is decreased (top-to-bottom), we observe a decrease in biofilm inhibition indicated by the increased presence of $P$. gingivalis cells (green). This figure displays molar equivalents of BAR ranging from 1.3 to $0.3 \mu \mathrm{M}$.

Robust formation of P. gingivalis/S. gordonii biofilms occurred in the PBS and avidin-NP control reactions, whereas significant inhibition of biofilm formation was seen when cells were incubated with the BAR-NP preparations. This indicates that NPs without BAR have no effect of $P$. gingivalis adherence to streptococci and subsequent biofilm formation and that inhibition of biofilm 
formation can be attributed to BAR peptide delivered by NPs.

The biofilm images were organized horizontally from left to right (see Figures 8 and 9) with the NP formulation containing the highest payload of peptide (5.66 $\mu \mathrm{g} / \mathrm{mg} \mathrm{NP})$ on the left and lowest payload $(1.20 \mu \mathrm{g} / \mathrm{mg} \mathrm{NP})$ on the right. In each vertical columns, the molar equivalent of BAR peptide delivered by each NP formulation is decreased. As shown in Figures 8 and 9, the biofilm inhibition increased with increasing BAR payload, even though each NP preparation delivered the same molar equivalent of BAR peptide.

This suggests that BAR-NPs with higher payloads interact with $P$. gingivalis at higher valency. In addition, as expected a dose dependent inhibition of biofilm formation occurred as the molar equivalent of peptide delivered by the various NP formulations was increased. Table 3 summarizes the percent biofilm inhibition calculated for each NP formulation and for each molar equivalent of BAR that was tested. 
Table 3 Maximum biofilm inhibition is observed for NPs functionalized with the highest valency of BAR peptide. Biofilm inhibition decreases as a function of NP valency and total BAR concentration.

\begin{tabular}{|c|c|c|}
\hline $\begin{array}{l}\text { Sample } \\
\text { valency ( } \mu \mathrm{g} \\
\text { BAR/mg NPs) }\end{array}$ & {$[B A R] \mu M$} & $\%$ Inhibition \\
\hline \multirow[t]{5}{*}{5.66} & 2.5 & 94.15 \\
\hline & 2 & 92.00 \\
\hline & 1.3 & 88.6 .0 \\
\hline & 0.7 & 61.82 \\
\hline & 0.3 & 30.70 \\
\hline \multirow[t]{5}{*}{2.90} & 2.5 & 80.96 \\
\hline & 2 & 77.91 \\
\hline & 1.3 & 75.45 \\
\hline & 0.7 & 39.93 \\
\hline & 0.3 & 29.41 \\
\hline \multirow[t]{5}{*}{1.48} & 2.5 & 68.30 \\
\hline & 2 & 65.08 \\
\hline & 1.3 & 63.58 \\
\hline & 0.7 & 40.48 \\
\hline & 0.3 & 24.71 \\
\hline \multirow[t]{5}{*}{1.20} & 2.5 & 59.83 \\
\hline & 2 & 52.92 \\
\hline & 1.3 & 43.12 \\
\hline & 0.7 & 17.05 \\
\hline & 0.3 & 14.93 \\
\hline
\end{tabular}




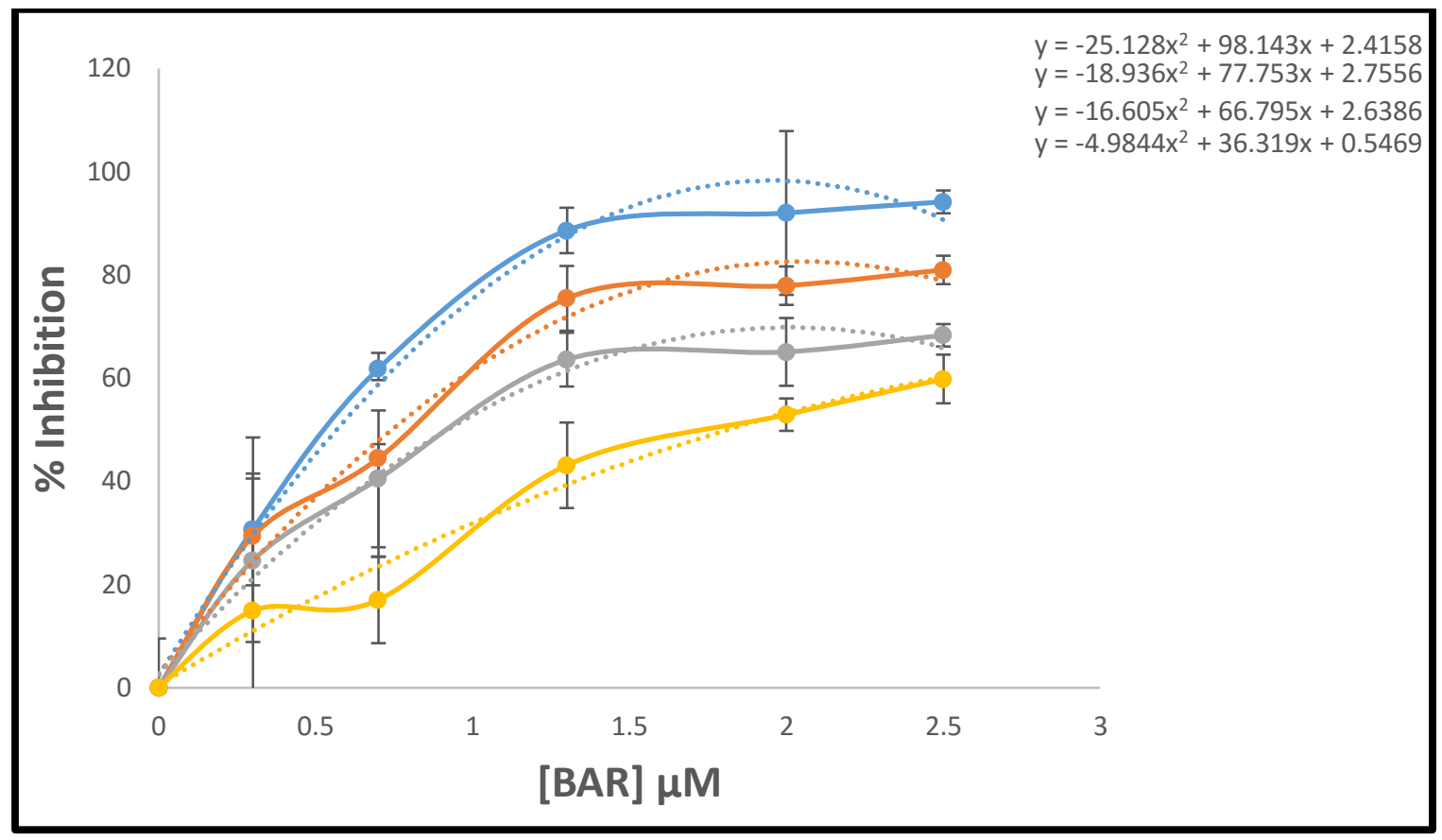

Figure 10 Biofilm inhibition curves showing BAR concentration versus percent inhibition for each NP surface modification group. Percent inhibition for 5.66 (blue), 2.90 (orange), 1.48 (grey) and 1.20 (yellow) $\mu \mathrm{g}$ BAR/mg NP are shown.

Overall, the NPs with the highest peptide valency exhibited the lowest $\mathrm{IC}_{50}$ values (Table 4). Conversely, as the valency of the BAR-NPs decreased, the $\mathrm{IC}_{50}$ value increased (Figures 10 and 11). The BAR-NPs bound to $P$. gingivalis significantly inhibited $P$. gingivalis-S.gordonii interaction as compared with PBS and avidinNPs controls $(p<0.05)$.

To determine the number of peptides corresponding to NP valency for the different formulations, the number of BAR peptides on each NP was calculated as a function of NP size, diameter, peptide MW, and conjugation density. The concentration of peptide conjugated per milligram NP: $5.66,2.90,1.48$ and 1.20 $\mu \mathrm{g} \mathrm{BAR/mg} \mathrm{NPs} \mathrm{(Table} \mathrm{2),} \mathrm{corresponded} \mathrm{to} \mathrm{2140,} \mathrm{1089,} 556$ and 451 peptides 
per NP, respectively.

Table 4 As the input BAR concentration decreases, the $I \mathrm{IC}_{50}$ increases

\begin{tabular}{|c|c|c|c|}
\hline Sample & $\begin{array}{c}\text { Input BAR } \\
\text { concentration } \\
\mu \mathrm{g} / \mathrm{mg} \text { NPs }\end{array}$ & $\begin{array}{c}\text { Output BAR } \\
\text { concentration } \\
\mu \mathrm{g} / \mathrm{mg} \text { NPs }\end{array}$ & $\mathrm{IC}_{50} \boldsymbol{\mu M}$ \\
\hline A & 71 & 5.66 & 0.56 \\
\hline B & 35.5 & 2.90 & 0.74 \\
C & 17.8 & 1.48 & 0.91 \\
\hline D & 8.9 & 1.20 & 1.81 \\
\hline
\end{tabular}

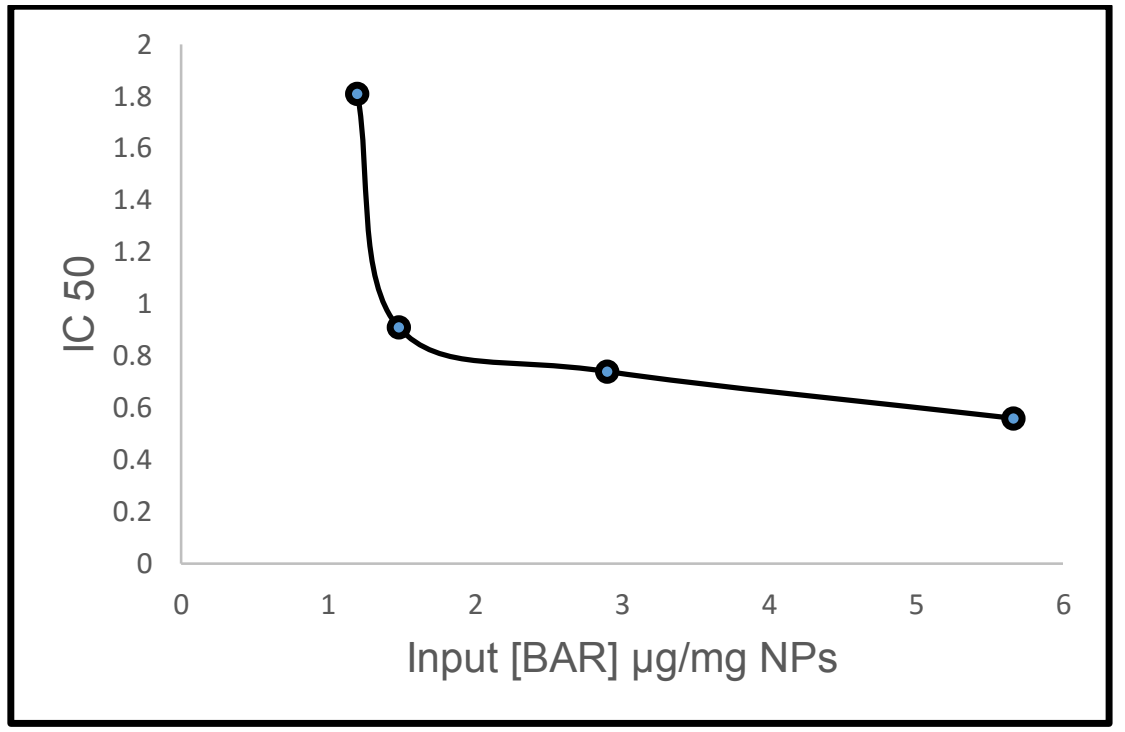

Figure 11 The lowest $\mathrm{IC}_{50}$ is achieved in the sample with the highest valency of BAR peptide. 


\section{Biofilm Inhibition Assay with BAR-Fc Fusion}

The BAR-Fc fusion biofilm inhibition assay was conducted similar to the BAR-NP experiment. The BAR-Fc fusion concentrations (dimer) used to determine biofilm inhibition were $0.25,0.5$, and $1 \mu \mathrm{M}$ BAR-Fc. For control reactions, $P$. gingivalis was treated with defined concentrations of soluble $\operatorname{BAR}(0.5,1.0$ and $2 \mu \mathrm{M})$. Control reactions consisted of $P$. gingivalis incubated with $A b$ alone or with buffer alone. The biofilm images along with the controls are shown in Figure 12. In addition to synthesizing the dimer fusion protein, we attempted to synthesize a tetramer fusion protein. During the synthesis process, there were challenges in the expression and purification of protein. Future experiments will seek to address this issue. 

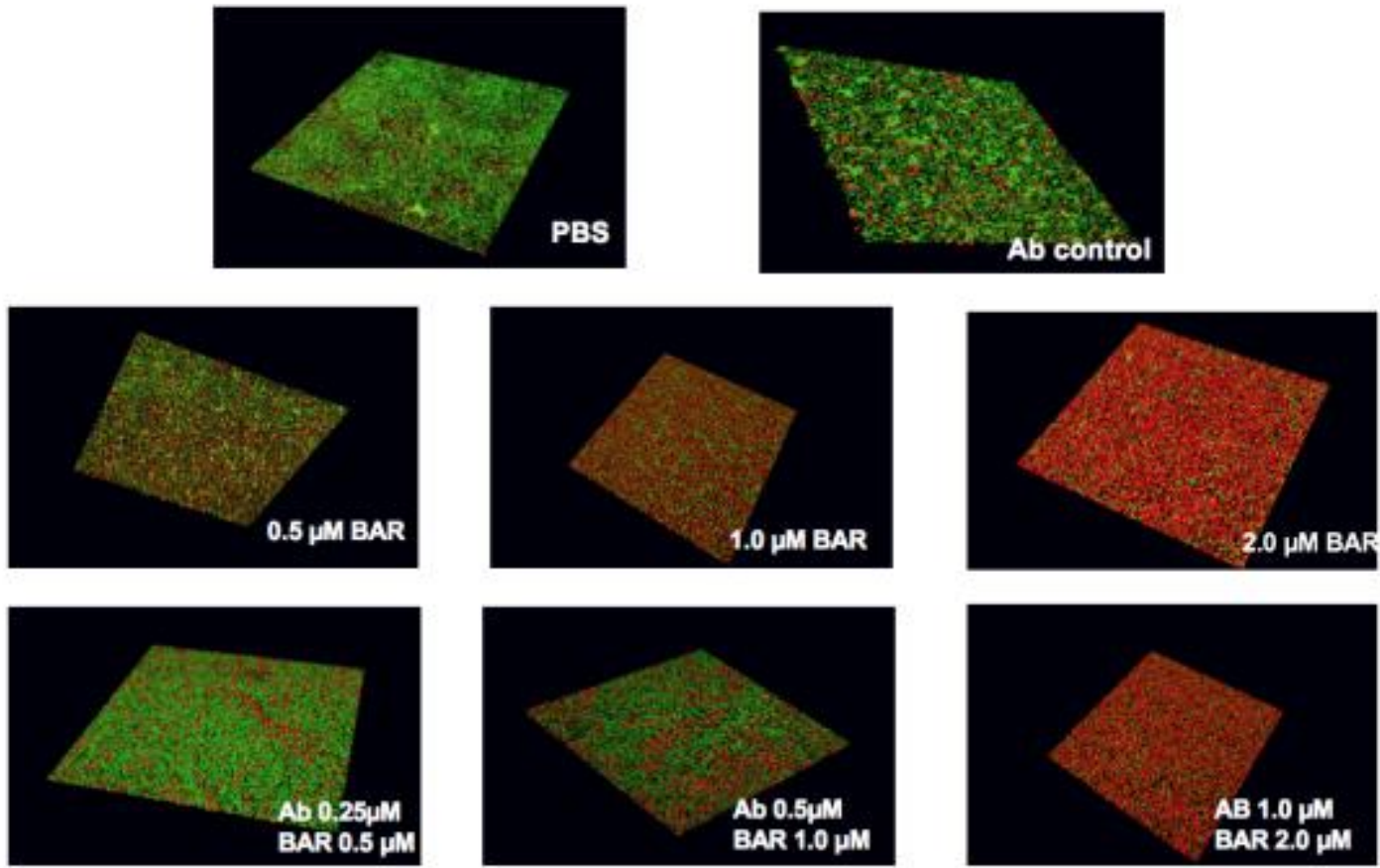

Figure 12 BAR-Fc inhibition of $P$. gingivalis adherence to $S$. gordonii. Biofilms were visualized by confocal microscopy and image stacks were assembled using Volocity image analysis software. Red cells represent $S$. gordonii and green cells represent $P$. gingivalis. The concentrations indicated on the images represent BAR peptide equivalents conjugated to the antibody.

Figure 12 shows that as the amount of BAR peptide is increased from $0.5 \mu \mathrm{M}$ $(\mathrm{Ab}=0.25 \mu \mathrm{M})$ to $2 \mu \mathrm{M}(\mathrm{Ab}=1 \mu \mathrm{M})$, there is a decrease in the number of $P$. gingivalis cells (green cells) adhered to streptococci and increased inhibition of biofilm formation. As shown in Table 5, a dose-dependent increase in the percent inhibition of biofilm formation occurred as the amount of the BAR peptide increased. 
Table 5 A BAR-Fc fusion protein containing two molar equivalents of BAR was synthesized and tested against free peptide for biofilm inhibition. The table shows the input BAR amount versus percent inhibition for increasing concentrations of peptide in Ab-BAR fusion proteins. Percent inhibition was calculated by quantifying fluorescence of the confocal images and plotted against the equimolar amounts of BAR peptide present in each sample of the BAR-Ab fusion proteins. A dose-dependent response was observed.

\begin{tabular}{|c|c|c|}
\hline Sample & $\begin{array}{c}\text { Input BAR } \\
\text { amount }(\mu \mathrm{M})\end{array}$ & Percent Inhibition \\
\hline A & 0.5 & 10.77 \\
\hline B & 1.0 & 28.73 \\
\hline C & 2.0 & 63.78 \\
\hline
\end{tabular}

Table 6 shows that the $\mathrm{IC}_{50}$ for the Ab-BAR fusion peptide was approximately 1.6 $\mu \mathrm{M}$ which is similar to the $\mathrm{IC}_{50}$ of free BAR peptide. This indicates that for this particular formulation, the Ab-BAR fusion peptide was not more potent than soluble BAR peptide $(p<0.05)$.

Table 6 The $\mathrm{IC}_{50}$ of interaction for the Ab-BAR Fusion protein was determined to be $1.61 \mu \mathrm{M}$ which is similar to that of free BAR peptide

\begin{tabular}{|l|l|}
\hline Peptide & IC $\mathbf{5 0}$ \\
\hline BAR & $1.3 \mu \mathrm{M}$ \\
\hline Ab-BAR Fusion & $1.6 \mu \mathrm{M}$ \\
\hline & *Daep C.A., R.J. Lamont and D.R. Demuth. 2008. 576 \\
\hline
\end{tabular}




\section{CHAPTER 5}

\section{DISCUSSION}

While the oral cavity accommodates both anaerobic and aerobic organisms, the environment of the oral cavity poses an adverse environment for organism survival (Dalwai et al., 2006). Due to the action of saliva, which reduces the accumulation of bacteria by various mechanisms, the bacteria must struggle to survive and stay in the oral cavity (Dalwai et al., 2006). To counteract the effects of saliva, the initial colonization and adhesion of bacterial organisms to the tooth surface occurs via the acquired pellicle (Lindh et al., 2014). Subsequent bacterial adhesion and colonization occur with the help of contact-dependent signaling, leading to the initiation and development of polymicrobial biofilms (Donlan, 2002). These polymicrobial biofilms are comprised of a structured community of microorganisms that are adhered to the surface and enclosed in a self-generated matrix. Interaction within these biofilms can be mutualistic, commensalistic or antagonistic (Willems et al., 2016). These interactions contribute to the formation of subgingival biofilms that stimulate a cascade of chronic inflammatory reactions by the diseased tissue (Bao et al., 2014). Its initiation is attributed to the formation of subgingival biofilms that stimulate a cascade of chronic inflammatory reactions by the diseased tissue (Bao et al., 2014). Porphyromonas 
gingivalis, Tannerella forsythia and Treponema denticola are associated with the occurrence and severity of the disease and are found as a part of these biofilms (Bao et al., 2014). P. gingivalis is one of the 'red' complex bacteria and has been suggested to function as a keystone pathogen (Darveau et al., 2012). $P$. gingivalis can be cultivated easily and genetic tools are available to facilitate its study (Suzuki et al., 2013). For these reasons $P$. gingivalis has been extensively studied and is being targeted as a key organism to inhibit biofilm formation (Darveau et al., 2012; Suzuki et al., 2013). Mechanistically, P. gingivalis is an obligate anaerobe and its primary niche is the subgingival pocket, but before it can establish itself there it must survive within the relative aerobic supragingival pocket. To enable its survival, $P$. gingivalis interacts with a facultative anaerobe S. gordonii supragingivally. This interaction is an initial event in biofilm formation, and represents an ideal target to inhibit the colonization of $P$. gingivalis and combat the initial stages of periodontitis. (Daep et al., 2008; Darveau et al., 2012; Park et al., 2005).

The interaction between $S$. gordonii and $P$. gingivalis involves the Mfa1 of $P$. gingivalis binding to the SspB of S. gordonii (Cook et al., 1998; Daep et al., 2006; Park et al., 2005). Previous studies have suggested a specific region on SspB that is involved in the interaction (Daep et al., 2006). This area has been recognized as BAR (SspB Adhering Region) and studies have led to the development of a peptide (BAR) which is derived from the antigen I/II protein of S. gordonii ( Daep et al., 2006; Daep et al., 2008). BAR peptide has demonstrated potent inhibition of $P$. gingivalis adherence to $S$. gordonii. BAR 
also significantly reduced $P$. gingivalis virulence in mice which harbored $S$. gordonii and were subsequently inoculated with $P$. gingivalis. (Daep et al., 2011). Additionally, BAR peptide proved potent in a dual-species biofilm; however, its efficacy decreased in pre-formed and more complex biofilms, requiring increased quantities and longer duration of peptide incubation (Gummadi, 2013, unpublished). In efforts to improve potency and to achieve a concentrated dose of BAR at the target site, surface-modified multivalent BAR-PLGA NPs were constructed.

The consideration of multivalency in the design of therapeutic carriers has the potential to enhance the inhibitory potential of low affinity molecules by increasing the number of interactions and decreasing the dissociation rates (avidity), between the delivery carrier and its therapeutic binding target. (Chittasupho, 2012). Multivalent approaches have proven effective to block the attachment of the influenza virus to its target cell by an inhibitor which is multivalent (Mammen et al, 1998). Similarly, multivalent targeting approaches amplified angiotensin II receptor type 1 blockade in the eye and concomitantly deliver a therapeutic payload into ocular lesions. In this project we implemented the concepts of multivalency to create high avidity interactions between the BARmodified NPs and the bacterial binding receptors. We hypothesized that carriers with increased valency would increase the potency of the peptide (Chittasupho, 2012).

Nanoparticle technology has contributed to a variety of translational applications, 
demonstrating versatility and biocompatibility in the delivery of an assortment of cargo, including drugs, genes, and proteins. Recently, NPs have found use in various areas of restorative dentistry, minimally invasive dental procedures, cancer diagnosis and treatment, molecular imaging and implant dentistry (Mantri \& Mantri, 2013). Due to their high structural integrity, stability during storage, ease of preparation and functionalization, and controlled release capability, polymeric NPs are highly attractive as drug delivery vehicles (Cheow \& Hadinoto, 2014).

Recent studies employing NPs for oral applications, have shown that BAR-NPs are more potent than the soluble BAR in inhibiting $P$. gingivalis adherence to $S$. gordonii, and preventing biofilm formation (Steinbach-Rankins, Demuth, unpublished). In this work, NPs were surface-modified with avidin to bind to the biotin of the BAR peptide. Avidin-biotin-ligand conjugation is considered to be one of the strongest non-covalent bonds and offers an efficient method of attaching the peptide to the NP surface (Bratthauer, 2010; Howarth et al., 2006). It was determined that each avidin has four biotin binding sites, but due to their close proximity to each other, leading to steric hindrance, we assumed that only two of the biotin-binding sites were available for biotinylated BAR conjugation (Howarth et al., 2006; Steinbach et al., 2016). The mechanism by which the PLGA-NPs enhanced the potency of the BAR peptide may be due to increased localized concentration of the BAR peptide or by promoting a multivalent binding interface to increase the avidity of BAR with $P$. gingivalis. In our experiments we hypothesized that BAR-NPs increased the avidity of the interaction by increasing 
the valency of BAR, thereby increasing the potency relative to free BAR peptide. We used two experimental assays to evaluate the efficacy as a function of increased BAR valency. Biofilm inhibition assays were performed using BARNPs and BAR-Fc fusion proteins, and the percent inhibition of $P$. gingivalis to $S$. gordonii adherence was compared to that of free BAR peptide.

First a direct approach was used to quantify the amount of BAR bound to the NP surface. BAR-Flc was reacted with NPs at concentrations of: $8.9,17.8,35.5,71$, 142, and $284 \mu \mathrm{g} \mathrm{BAR/mg} \mathrm{NPs.} \mathrm{We} \mathrm{varied} \mathrm{these} \mathrm{concentrations} \mathrm{around} \mathrm{a} \mathrm{three-}$ fold molar excess of BAR (71 $\mathrm{\mu g}$ BAR/mg NPs) to available binding sites and observed that at this concentration, all available avidin binding sites were saturated on the NP surface. The percentage of BAR bound to the NPs, relative to the input concentration remained constant $(24 \%)$ even upon increased concentrations of reactant BAR (e.g. 142 and $284 \mu \mathrm{g} \mathrm{BAR/mg} \mathrm{NPs).} \mathrm{In}$ comparison with previous experiments, in which the same amount of avidin was added to $100 \mathrm{mg}$ versus $50 \mathrm{mg}$ PLGA NPs, half the amount of BAR was needed (71 vs. $142 \mu \mathrm{g}$ ) indicating that less avidin may be used during the synthesis process to induce similar binding results. In our experiments, we achieved $1.20 \pm$ $0.68,1.48 \pm 0.17,2.90 \pm 0.16$, and $5.66 \pm 0.20 \mu \mathrm{g} \mathrm{BAR} / \mathrm{mg} \mathrm{NPs}$, bound to the NP surface at input concentrations of $8.9,17.8,35.5$, and $71 \mu \mathrm{g} \mathrm{BAR/mg} \mathrm{NPs,}$ respectively, demonstrating very efficient binding.

To determine if this increase in the binding efficiency was attributed to an increase in valency, similar concentrations of BAR-NPs $(8.9,17.8,35.5,71,142$, and $284 \mu \mathrm{BAR} / \mathrm{mg} \mathrm{NPs}$ ) were reacted with $P$. gingivalis. $P$. gingivalis cells 
were subsequently incubated with immobilized S. gordonii to form biofilms. Five different equimolar BAR peptide concentrations $(0.3,0.7,1.3,2.0$, and $2.5 \mu \mathrm{M})$ for each batch of BAR-NPs (with differing valency) were evaluated. As the equimolar BAR NP concentration increased, biofilms were increasingly inhibited and $P$. gingivalis to $S$. gordonii interaction decreased. We also found out that the $50 \%$ inhibitory concentration was highest for the BAR-NP sample that had the maximum BAR density (valency) on the NP surface.

Next, we used a different platform to deliver BAR peptide - a BAR -Ab fusion protein. IgG was used in a dimer form and BAR peptide was fused to it using a novel plant based production platform, with one molecule of antibody carrying two molecules of BAR (Hamorsky et al., 2013). The biofilms were formed using a concentration range of BAR: $0.5 \mu \mathrm{M}(\mathrm{Ab}=0.25 \mu \mathrm{M}), 1 \mu \mathrm{M}(\mathrm{Ab}=0.5 \mu \mathrm{M})$, and $2 \mu \mathrm{M}$ $(A b=1 \mu M)$, and biofilm inhibition was quantified. Although a linear increase in the percent inhibition was observed as the amount of BAR peptide increased, the $\mathrm{IC}_{50}(1.6 \mu \mathrm{M})$ was similar to that of free BAR alone $\left(\mathrm{IC}_{50}=1.3 \mu \mathrm{M}\right)$. Hence, to make the BAR-Fc fusion more potent, we believe that more BAR molecules need to be fused per Ab molecule. As we calculated before, 451 molecules of BAR are present per NP in $8.9 \mu \mathrm{g} \mathrm{BAR/mg} \mathrm{NP}$ (lowest valency) batch as compared to 2 molecules in a BAR-Fc fusion, it is not surprising that we did not see an increase in potency of BAR in BAR-Fc fusion proteins. Our data, therefore, suggests that increased number of BAR molecules are required to improve the fusion protein potency. We also speculate that if the tetramer form of BAR-Fc fusion (Fc') were to be tested, we would not have been able to observe an increase in the potency 
of that particular formulation as we believe that more than 2 but less than 451 molecules of BAR are required to achieve the desired effect. This comparison highlights differences between platforms that enable low, relative to high density modification; however, we acknowledge that there are likely differences in available BAR spatial arrangements between NP and Ab carriers. Therefore, even equivalent amounts of BAR on each carrier may exhibit dissimilar effects in binding, due to platform differences.

This concept of the increased percent inhibition due to an increase in valency, provides us a solid framework to develop therapeutics, by designing NPs to specifically target microorganisms more effectively and safely. As recent studies suggest that $P$. gingivalis plays a significant role in altering the host-microbe homeostasis, new delivery platforms for BAR peptide seek to block $P$. gingivalis interactions more effectively. We understand that the etiology of periodontitis is very complex and there might be many more bacterial interactions simultaneously involved, which might have significant impact on disease progression. The surface-modified NPs could, therefore, be applied to target other bacterial interactions in the oral cavity and combat the bacterial colonization, thereby, periodontitis. This could be achieved by modifying the NPs with peptides pertaining to particular interactions.

The experimental results suggest that by increasing NP valency, we can obtain increased avidity and potency of the peptide. This paves the way for lower concentrations of BAR to be used, while still achieving similar efficacy. Constant flow of saliva in the oral cavity and the intake of food and water may regularly 
wash out the therapeutic peptides (BAR) which would decrease the effectiveness of BAR. Due to the efficacy of BAR-NPs at both high and low concentrations, relative to free BAR peptide, this approach may prove very beneficial. Since BAR peptide is relatively expensive to produce, this method of conjugating BAR to NPs may offer a more cost effective alternative for delivery. Additionally, because of the conjugation with NPs, BAR can be delivered locally in a concentrated form to increase BAR effectiveness. For translational applications, BAR-modified NPs may, eventually, be prescribed as mouthwashes or chewing gums after oral prophylaxis procedures done in a dental office. This would offer a cure for periodontitis and not just a preventive treatment like scaling or gingival surgery.

We are still establishing effect of BAR-modified NPs on pre-formed and more complex biofilms. Future directions of this research project will study the effect of BAR-NPs in established biofilms as well as in more complex biofilms with Fusobacterium nucleatum, in vitro. From a design perspective, decreased avidin reactant may be used for conjugation to the NP surface, which may further increase the potency of the BAR peptide. Experiments will also be conducted to determine the toxicity of surface-modified NPs in human gingival cells, with eventual translation to animal models. Regarding BAR-Fc fusion proteins, additional modifications of the non-Fc binding BAR Abs will be pursued to enhance their therapeutic potential. For example, they may be constructed in tetramer or higher valency forms, which would incorporate four or more molecules for BAR per molecule of Ab. These formulations may prove promising 
for inhibition. To benefit from both delivery technologies, we may investigate AbBAR-NPs, to enhance and prolong effects in the oral cavity. Our long-term goal is to develop a therapeutic that can be approved to be tested in clinical trials. We envision that clinical trials will require recognizing that the oral cavity is a niche for many organisms. This would involve creating conditions that would harbor only the bacteria that need to be studied. We envision that clinical prevention and treatment may involve the administration of BAR peptide immediately after oral prophylaxis. With this, the number of $P$. gingivalis cells that recolonize the oral cavity with time can be used as an outcome to assess the efficacy of BAR-NP preparations. For example, one possible approach is to subject patients to oral prophylaxis and then provide one group with a mouth rinse containing BAR-NPs and a second group with a placebo formulation. The kinetics of $P$. gingivalis recolonization would serve as the outcome to determine the effectiveness of the treatment protocol. In these experiments, patient compliance must be monitored very carefully. Overall, BAR-NPs look very promising and may pave the way to develop therapeutics that would actually prevent biofilms from forming and thereby reducing the incidence of chronic periodontitis. 


\section{REFERENCES}

1. Abiodun-Solanke, I. M. F., Ajayi, D. M., \& Arigbede, A. O. (2014). Nanotechnology and its Application in Dentistry. Annals of Medical and Health Sciences Research, 4(Suppl 3), S171-S177. doi:10.4103/21419248.141951

2. Adeyemi, O. S., \& Sulaiman, F. A. (2015). Evaluation of metal nanoparticles for drug delivery systems. J Biomed Res, 29(2), 145-149. doi:10.7555/jbr.28.20130096

3. Albandar, J. M. (2011). Underestimation of periodontitis in NHANES surveys. J Periodontol, 82(3), 337-341. doi:10.1902/jop.2011.100638

4. AlJehani, Y. A. (2014). Risk Factors of Periodontal Disease: Review of the Literature. International Journal of Dentistry, 2014, 182513. doi:10.1155/2014/182513

5. Allaker, R. P. (2010). The use of nanoparticles to control oral biofilm formation. J Dent Res, 89(11), 1175-1186. doi:10.1177/0022034510377794

6. Armstrong, W. G. (1968). Origin and nature of the acquired pellicle. Proceedings of the Royal Society of Medicine, 61(9), 923-930.

7. Arvizo, R. R., Bhattacharyya, S., Kudgus, R., Giri, K., Bhattacharya, R., \& Mukherjee, P. (2012). Intrinsic Therapeutic Applications of Noble Metal Nanoparticles: Past, Present and Future. Chemical Society Reviews, 41(7), 2943-2970. doi:10.1039/c2cs15355f

8. Bao, K., Belibasakis, G. N., Thurnheer, T., Aduse-Opoku, J., Curtis, M. A., \& Bostanci, N. (2014). Role of Porphyromonas gingivalis gingipains in multi-species biofilm formation. BMC Microbiology, 14(1), 258. doi:10.1186/s12866-014-0258-7

9. Batra, P., \& Miglani, R. Antibacterial properties of retainers with silver nanoparticles. American Journal of Orthodontics and Dentofacial Orthopedics, 150(2), 208-209. doi:10.1016/j.ajodo.2016.06.007

10. Bjarnsholt, T. (2013). The role of bacterial biofilms in chronic infections. APMIS Supp/(136), 1-51. doi:10.1111/apm.12099 
11. Blango, M. G., \& Mulvey, M. A. (2009). Bacterial Landlines: Contactdependent Signaling in Bacterial Populations. Current opinion in microbiology, 12(2), 177-181. doi:10.1016/j.mib.2009.01.011

12. Bonduelle, C., Oliveira, H., Gauche, C., Huang, J., Heise, A., \& Lecommandoux, S. (2016). Multivalent effect of glycopolypeptide based nanoparticles for galectin binding. Chem Commun (Camb), 52(75), 1125111254. doi:10.1039/c6cc06437j

13. Bratthauer, G. L. (2010). The avidin-biotin complex (ABC) method and other avidin-biotin binding methods. Methods Mol Biol, 588, 257-270. doi:10.1007/978-1-59745-324-0_26

14. Brogden, K. A., \& Guthmiller, J. M. (2002). Polymicrobial Diseases: ASM Press.

15. Chandki, R., Banthia, P., \& Banthia, R. (2011). Biofilms: A microbial home. Journal of Indian Society of Periodontology, 15(2), 111-114. doi:10.4103/0972-124X.84377

16. Cheow, W. S., \& Hadinoto, K. (2014). Antibiotic polymeric nanoparticles for biofilm-associated infection therapy. Methods Mol Biol, 1147, 227-238. doi:10.1007/978-1-4939-0467-9_16

17. Chittasupho, C. (2012). Multivalent ligand: design principle for targeted therapeutic delivery approach. Ther Deliv, 3(10), 1171-1187.

18. Chung, W. O., Demuth, D. R., \& Lamont, R. J. (2000). Identification of a Porphyromonas gingivalis receptor for the Streptococcus gordonii SspB protein. Infect Immun, 68(12), 6758-6762.

19. Cook, G. S., Costerton, J. W., \& Lamont, R. J. (1998). Biofilm formation by Porphyromonas gingivalis and Streptococcus gordonii. J Periodontal Res, 33(6), 323-327.

20. Costerton, J. W., Cheng, K. J., Geesey, G. G., Ladd, T. I., Nickel, J. C., Dasgupta, M., \& Marrie, T. J. (1987). Bacterial biofilms in nature and disease. Annu Rev Microbiol, 41, 435-464. doi:10.1146/annurev.mi.41.100187.002251

21. Curtis, Michael A., Zenobia, C., \& Darveau, Richard P. (2011). The Relationship of the Oral Microbiotia to Periodontal Health and Disease. Cell Host \& Microbe, 10(4), 302-306. doi:http://dx.doi.org/10.1016/j.chom.2011.09.008

22. Daep, C. A., James, D. M., Lamont, R. J., \& Demuth, D. R. (2006). Structural characterization of peptide-mediated inhibition of Porphyromonas gingivalis biofilm formation. Infect Immun, 74(10), 57565762. doi:10.1128/iai.00813-06

23. Daep, C. A., Lamont, R. J., \& Demuth, D. R. (2008). Interaction of Porphyromonas gingivalis with Oral Streptococci Requires a Motif That 
Resembles the Eukaryotic Nuclear Receptor Box Protein-Protein Interaction Domain. Infect Immun, 76(7), 3273-3280.

doi:10.1128/IAI.00366-08

24. Daep, C. A., Novak, E. A., Lamont, R. J., \& Demuth, D. R. (2011). Structural Dissection and In Vivo Effectiveness of a Peptide Inhibitor of Porphyromonas gingivalis Adherence to Streptococcus gordonii. Infect Immun, 79(1), 67-74. doi:10.1128/IAI.00361-10

25. Dalwai, F., Spratt, D. A., \& Pratten, J. (2006). Modeling shifts in microbial populations associated with health or disease. Appl Environ Microbiol, 72(5), 3678-3684. doi:10.1128/aem.72.5.3678-3684.2006

26. Darveau, R. P. (2010a). Periodontitis: a polymicrobial disruption of host homeostasis. Nat Rev Microbiol, 8(7), 481-490. doi:10.1038/nrmicro2337

27. Darveau, R. P. (2010b). Periodontitis: a polymicrobial disruption of host homeostasis. Nat Rev Microbiol, 8. doi:10.1038/nrmicro2337

28. Darveau, R. P., Hajishengallis, G., \& Curtis, M. A. (2012). Porphyromonas gingivalis as a potential community activist for disease. J Dent Res, 91(9), 816-820. doi:10.1177/0022034512453589

29. De Jong, W. H., \& Borm, P. J. A. (2008). Drug delivery and nanoparticles: Applications and hazards. International Journal of Nanomedicine, 3(2), 133-149.

30. Demuth, D. R., Irvine, D. C., Costerton, J. W., Cook, G. S., \& Lamont, R. J. (2001). Discrete Protein Determinant Directs the Species-Specific Adherence of Porphyromonas gingivalis to Oral Streptococci. Infect Immun, 69(9), 5736-5741. doi:10.1128/IAI.69.9.5736-5741.2001

31. Dhadse, P., Gattani, D., \& Mishra, R. (2010). The link between periodontal disease and cardiovascular disease: How far we have come in last two decades ? Journal of Indian Society of Periodontology, 14(3), 148-154. doi:10.4103/0972-124X.75908

32. Dhadse, P., Gattani, D., \& Mishra, R. (2010). The link between periodontal disease and cardiovascular disease: How far we have come in last two decades ? J Indian Soc Periodontol, 14(3), 148-154. doi:10.4103/0972$124 \times .75908$

33. Diaz, P. I., Chalmers, N. I., Rickard, A. H., Kong, C., Milburn, C. L., Palmer, R. J., \& Kolenbrander, P. E. (2006). Molecular Characterization of Subject-Specific Oral Microflora during Initial Colonization of Enamel. Applied and Environmental Microbiology, 72(4), 2837-2848. doi:10.1128/AEM.72.4.2837-2848.2006

34. Dickinson, B. C., Moffatt, C. E., Hagerty, D., Whitmore, S. E., Brown, T. A., Graves, D. T., \& Lamont, R. J. (2011). Interaction of oral bacteria with gingival epithelial cell multilayers. Mol Oral Microbiol, 26(3), 210-220. doi:10.1111/j.2041-1014.2011.00609.x 
35. Donlan, R. M. (2002). Biofilms: Microbial Life on Surfaces. Emerging Infectious Diseases, 8(9), 881-890. doi:10.3201/eid0809.020063

36. Eke, P. I., Dye, B. A., Wei, L., Slade, G. D., Thornton-Evans, G. O., Borgnakke, W. S., ... Genco, R. J. (2015). Update on Prevalence of Periodontitis in Adults in the United States: NHANES 2009 - 2012. J Periodontol, 86(5), 611-622. doi:10.1902/jop.2015.140520

37. Eke, P. I., Dye, B. A., Wei, L., Slade, G. D., Thornton-Evans, G. O., Borgnakke, W. S., .. Genco, R. J. (2015). Update on Prevalence of Periodontitis in Adults in the United States: NHANES 2009 to 2012. $J$ Periodontol, 86(5), 611-622. doi:10.1902/jop.2015.140520

38. Fahmy, T. M., Samstein, R. M., Harness, C. C., \& Mark Saltzman, W. (2005). Surface modification of biodegradable polyesters with fatty acid conjugates for improved drug targeting. Biomaterials, 26(28), 5727-5736. doi:10.1016/j.biomaterials.2005.02.025

39. Garrett, T. R., Bhakoo, M., \& Zhang, Z. (2008). Bacterial adhesion and biofilms on surfaces. Progress in Natural Science, 18(9), 1049-1056. doi:http://dx.doi.org/10.1016/j.pnsc.2008.04.001

40. Gautam, D. K., Jindal, V., Gupta, S. C., Tuli, A., Kotwal, B., \& Thakur, R. (2011). Effect of cigarette smoking on the periodontal health status: $A$ comparative, cross sectional study. Journal of Indian Society of Periodontology, 15(4), 383-387. doi:10.4103/0972-124X.92575

41. Ge, L., Li, Q., Wang, M., Ouyang, J., Li, X., \& Xing, M. M. Q. (2014). Nanosilver particles in medical applications: synthesis, performance, and toxicity. International Journal of Nanomedicine, 9, 2399-2407. doi:10.2147/IJN.S55015

42. Gelperina, S., Kisich, K., Iseman, M. D., \& Heifets, L. (2005). The Potential Advantages of Nanoparticle Drug Delivery Systems in Chemotherapy of Tuberculosis. American Journal of Respiratory and Critical Care Medicine, 172(12), 1487-1490. doi:10.1164/rccm.200504-613PP

43. Gobbo, O. L., Sjaastad, K., Radomski, M. W., Volkov, Y., \& Prina-Mello, A. (2015). Magnetic Nanoparticles in Cancer Theranostics. Theranostics, 5(11), 1249-1263. doi:10.7150/thno.11544

44. Grenier, D. (1992). Demonstration of a bimodal coaggregation reaction between Porphyromonas gingivalis and Treponema denticola. Oral Microbiol Immunol, 7(5), 280-284.

45. Hajishengallis, G. (2014). Immunomicrobial pathogenesis of periodontitis: keystones, pathobionts, and host response. Trends Immunol, 35(1), 3-11. doi:10.1016/j.it.2013.09.001

46. Hajishengallis, G., \& Lamont, R. J. (2012). Beyond the red complex and into more complexity: the polymicrobial synergy and dysbiosis (PSD) model of periodontal disease etiology. Mol Oral Microbiol, 27(6), 409-419. doi:10.1111/j.2041-1014.2012.00663.x 
47. Hamorsky, K. T., Grooms-Williams, T. W., Husk, A. S., Bennett, L. J., Palmer, K. E., \& Matoba, N. (2013). Efficient Single Tobamoviral VectorBased Bioproduction of Broadly Neutralizing Anti-HIV-1 Monoclonal Antibody VRC01 in Nicotiana benthamiana Plants and Utility of VRC01 in Combination Microbicides. Antimicrobial Agents and Chemotherapy, 57(5), 2076-2086. doi:10.1128/AAC.02588-12

48. Hennig, R., Ohlmann, A., Staffel, J., Pollinger, K., Haunberger, A., Breunig, M., .. . Goepferich, A. (2015). Multivalent nanoparticles bind the retinal and choroidal vasculature. J Control Release, 220(Pt A), 265-274. doi:10.1016/j.jconrel.2015.10.033

49. Herranz, F., Almarza, E., RodríGuez, I., Salinas, B., Rosell, Y., Desco, M., . . Ruiz-Cabello, J. (2011). The Application of Nanoparticles in Gene Therapy and Magnetic Resonance Imaging. Microscopy Research and Technique, 74(7), 577-591. doi:10.1002/jemt.20992

50. Hong, S., Leroueil, P. R., Majoros, I. J., Orr, B. G., Baker Jr, J. R., \& Banaszak Holl, M. M. (2007). The Binding Avidity of a Nanoparticle-Based Multivalent Targeted Drug Delivery Platform. Chemistry \& Biology, 14(1), 107-115. doi:http://dx.doi.org/10.1016/j.chembiol.2006.11.015

51. Howarth, M., Chinnapen, D. J. F., Gerrow, K., Dorrestein, P. C., Grandy, M. R., Kelleher, N. L., . . . Ting, A. Y. (2006). A monovalent streptavidin with a single femtomolar biotin binding site. Nature methods, 3(4), 267273. doi:10.1038/NMETHXXX

52. Ikuma, K., Decho, A. W., \& Lau, B. L. T. (2015). When nanoparticles meet biofilms-interactions guiding the environmental fate and accumulation of nanoparticles. Frontiers in Microbiology, 6, 591. doi:10.3389/fmicb.2015.00591

53. Kafshgari, M. H., Cavallaro, A., Delalat, B., Harding, F. J., McInnes, S. J., Mäkilä, E., . . Voelcker, N. H. (2014). Nitric oxide-releasing porous silicon nanoparticles. Nanoscale Research Letters, 9(1), 333. doi:10.1186/1556276x-9-333

54. Kinder, S. A., \& Holt, S. C. (1989). Characterization of coaggregation between Bacteroides gingivalis T22 and Fusobacterium nucleatum T18. Infect Immun, 57(11), 3425-3433.

55. Klepac-Ceraj, V., Patel, N., Song, X., Holewa, C., Patel, C., Kent, R., . . . Soukos, N. S. (2011). Photodynamic effects of methylene blue-loaded polymeric nanoparticles on dental plaque bacteria. Lasers in surgery and medicine, 43(7), 600-606. doi:10.1002/lsm.21069

56. Kolenbrander, P. E., \& Andersen, R. N. (1989). Inhibition of coaggregation between Fusobacterium nucleatum and Porphyromonas (Bacteroides) gingivalis by lactose and related sugars. Infect Immun, 57(10), 3204-3209.

57. Kontermann, R. E. (2016). Half-life extended biotherapeutics. Expert Opin Biol Ther, 16(7), 903-915. doi:10.1517/14712598.2016.1165661 
58. Koziel, J., Mydel, P., \& Potempa, J. (2014). The Link Between Periodontal Disease and Rheumatoid Arthritis: An Updated Review. Curr Rheumatol Rep, 16(3). doi:10.1007/s11926-014-0408-9

59. Lamont, R. J., El-Sabaeny, A., Park, Y., Cook, G. S., Costerton, J. W., \& Demuth, D. R. (2002). Role of the Streptococcus gordonii SspB protein in the development of Porphyromonas gingivalis biofilms on streptococcal substrates. Microbiology, 148(Pt 6), 1627-1636. doi:10.1099/00221287148-6-1627

60. Lamont, R. J., \& Jenkinson, H. F. (1998). Life below the gum line: pathogenic mechanisms of Porphyromonas gingivalis. Microbiol Mol Biol Rev, 62(4), 1244-1263.

61. Li, L., \& Huh, K. M. (2014). Polymeric nanocarrier systems for photodynamic therapy. Biomaterials Research, 18, 19. doi:10.1186/20557124-18-19

62. Lindh, L., Aroonsang, W., Sotres, J., \& Arnebrant, T. (2014). Salivary pellicles. Monogr Oral Sci, 24, 30-39. doi:10.1159/000358782

63. Loesche, W. J. (1992). The specific plaque hypothesis and the antimicrobial treatment of periodontal disease. Dent Update, 19(2), 68, 70$62,74$.

64. Makadia, H. K., \& Siegel, S. J. (2011). Poly Lactic-co-Glycolic Acid (PLGA) as Biodegradable Controlled Drug Delivery Carrier. Polymers, 3(3), 1377-1397. doi:10.3390/polym3031377

65. Mammen, M., Choi, S.-K., \& Whitesides, G. M. (1998). Polyvalent Interactions in Biological Systems: Implications for Design and Use of Multivalent Ligands and Inhibitors. Angewandte Chemie International Edition, 37(20), 2754-2794. doi:10.1002/(SICI)15213773(19981102)37:20<2754::AID-ANIE2754>3.0.CO;2-3

66. Mantri, S. S., \& Mantri, S. P. (2013). The nano era in dentistry. Journal of Natural Science, Biology, and Medicine, 4(1), 39-44. doi:10.4103/09769668.107258

67. Marsh, P. D. (1994). Microbial ecology of dental plaque and its significance in health and disease. Adv Dent Res, 8(2), 263-271.

68. Marsh, P. D. (2006). Dental plaque as a biofilm and a microbial community - implications for health and disease. BMC Oral Health, 6(Suppl 1), S14S14. doi:10.1186/1472-6831-6-S1-S14

69. Martin-Banderas, L., Duran-Lobato, M., Munoz-Rubio, I., Alvarez-Fuentes, J., Fernandez-Arevalo, M., \& Holgado, M. A. (2013). Functional PLGA NPs for oral drug delivery: recent strategies and developments. Mini Rev Med Chem, 13(1), 58-69. 
70. McMillan, J., Batrakova, E., \& Gendelman, H. E. (2011). Cell Delivery of Therapeutic Nanoparticles. Progress in molecular biology and translational science, 104, 563-601. doi:10.1016/B978-0-12-416020-0.00014-0

71. Mody, V. V., Siwale, R., Singh, A., \& Mody, H. R. (2010). Introduction to metallic nanoparticles. Journal of Pharmacy and Bioallied Sciences, 2(4), 282-289. doi:10.4103/0975-7406.72127

72. Mudshinge, S. R., Deore, A. B., Patil, S., \& Bhalgat, C. M. (2011). Nanoparticles: Emerging carriers for drug delivery. Saudi Pharmaceutical Journal, 19(3), 129-141. doi:http://dx.doi.org/10.1016/i.jsps.2011.04.001

73. Niazi, J. H., \& Gu, M. B. (2009). Toxicity of Metallic Nanoparticles in Microorganisms- a Review. In Y. J. Kim, U. Platt, M. B. Gu, \& H. Iwahashi (Eds.), Atmospheric and Biological Environmental Monitoring (pp. 193206). Dordrecht: Springer Netherlands.

74. O'Toole, G., Kaplan, H. B., \& Kolter, R. (2000). Biofilm formation as microbial development. Annu Rev Microbiol, 54, 49-79. doi:10.1146/annurev.micro.54.1.49

75. Palza, H. (2015). Antimicrobial Polymers with Metal Nanoparticles. International Journal of Molecular Sciences, 16(1), 2099-2116. doi:10.3390/ijms16012099

76. Park, Y., Simionato, M. R., Sekiya, K., Murakami, Y., James, D., Chen, W., .. L Lamont, R. J. (2005). Short Fimbriae of Porphyromonas gingivalis and Their Role in Coadhesion with Streptococcus gordonii. Infect Immun, 73(7), 3983-3989. doi:10.1128/iai.73.7.3983-3989.2005

77. Park, Y., Simionato, M. R., Sekiya, K., Murakami, Y., James, D., Chen, W., . . Lamont, R. J. (2005). Short Fimbriae of Porphyromonas gingivalis and Their Role in Coadhesion with Streptococcus gordonii. Infect Immun, 73(7), 3983-3989. doi:10.1128/iai.73.7.3983-3989.2005

78. Puglia, C., Blasi, P., Rizza, L., Schoubben, A., Bonina, F., Rossi, C., \& Ricci, M. (2008). Lipid nanoparticles for prolonged topical delivery: An in vitro and in vivo investigation. International Journal of Pharmaceutics, 357(1-2), 295-304. doi:http://dx.doi.org/10.1016/j.ijpharm.2008.01.045

79. Rocas, I. N., Siqueira, J. F., Jr., Santos, K. R., \& Coelho, A. M. (2001). "Red complex" (Bacteroides forsythus, Porphyromonas gingivalis, and Treponema denticola) in endodontic infections: a molecular approach. Oral Surg Oral Med Oral Pathol Oral Radiol Endod, 91(4), 468-471. doi:10.1067/moe.2001.114379

80. Rosan, B., \& Lamont, R. J. (2000). Dental plaque formation. Microbes Infect, 2(13), 1599-1607.

81. Rosier, B. T., De Jager, M., Zaura, E., \& Krom, B. P. (2014). Historical and contemporary hypotheses on the development of oral diseases: are we there yet? Frontiers in Cellular and Infection Microbiology, 4, 92. doi:10.3389/fcimb.2014.00092 
82. Senior, K., Muller, S., Schacht, V. J., \& Bunge, M. (2012). Antimicrobial precious-metal nanoparticles and their use in novel materials. Recent Pat Food Nutr Agric, 4(3), 200-209.

83. Singh, R., \& Lillard, J. W. (2009). Nanoparticle-based targeted drug delivery. Experimental and molecular pathology, 86(3), 215-223. doi:10.1016/j.yexmp.2008.12.004

84. Sirelkhatim, A., Mahmud, S., Seeni, A., Kaus, N. H. M., Ann, L. C., Bakhori, S. K. M., . . Mohamad, D. (2015). Review on Zinc Oxide Nanoparticles: Antibacterial Activity and Toxicity Mechanism. Nano-Micro Letters, 7(3), 219-242. doi:10.1007/s40820-015-0040-x

85. Steinbach, J. M., Seo, Y. E., \& Saltzman, W. M. (2016). Cell penetrating peptide-modified poly(lactic-co-glycolic acid) nanoparticles with enhanced cell internalization. Acta Biomater, 30, 49-61.

doi:10.1016/j.actbio.2015.11.029

86. Strohl, W. R. (2015). Fusion Proteins for Half-Life Extension of Biologics as a Strategy to Make Biobetters. BioDrugs, 29(4), 215-239. doi:10.1007/s40259-015-0133-6

87. Suzuki, N., Yoneda, M., \& Hirofuji, T. (2013). Mixed Red-Complex Bacterial Infection in Periodontitis. International Journal of Dentistry, 2013, 587279. doi:10.1155/2013/587279

88. Wang, E. C., \& Wang, A. Z. (2014). Nanoparticles and their applications in cell and molecular biology. Integr Biol (Camb), 6(1), 9-26.

doi:10.1039/c3ib40165k

89. Wang, L.-S., Gupta, A., \& Rotello, V. M. (2016). Nanomaterials for the Treatment of Bacterial Biofilms. ACS Infectious Diseases, 2(1), 3-4. doi:10.1021/acsinfecdis.5b00116

90. Wang, M., Ravindranath, S. R., Rahim, M. K., Botvinick, E., \& Haun, J. B. (2016). The evolution of multivalent nanoparticle adhesion via specific molecular interactions. Langmuir. doi:10.1021/acs.langmuir.6b03014

91. Willems, H. M., Xu, Z., \& Peters, B. M. (2016). Polymicrobial Biofilm Studies: From Basic Science to Biofilm Control. Curr Oral Health Rep, 3(1), 36-44. doi:10.1007/s40496-016-0078-y 


\section{CURRICULUM VITAE}

NAME: $\quad$ Ankita Jain

\section{ADDRESS}

Dept. of Oral Immunology and Infectious Disease University of Louisville School of Dentistry 501 South Preston Louisville, KY 40202

DOB

Khanna, Punjab State, India. - June 20, 1987

EDUCATION \& TRAINING

B.D.S, Dental Surgery Himachal Pradesh University

2005-2010

DENTAL EXPERIENCE

Associate Dentist - Dabur Dhanvantry Hospital, Chandigarh, India April 2011 - June 2011

Consultant Dentist - Dabur Dhanvantry Hospital, Chandigarh, India July 2011 - July 2015

PROFESSIONAL SOCIETIES

National Student Research Group (NSRG)

August 2015 - Ongoing

Indian Dental Association (IDA)

January 2012 - Ongoing 


\section{PRESENTATIONS}

Research!Louisville, Louisville, KY

October 2016

Poster Presentation: Mechanism of Interaction of Peptide Modified Nanoparticles with Porphyromonas gingiva. 